\title{
Shales at All Scales: Exploring Coupled Processes in Mudrocks
}

Anastasia G. Ilgen ${ }^{1}$, Jason E. Heath ${ }^{2}$, I. Yucel Akkutlu ${ }^{3}$, L. Taras Bryndzia ${ }^{4}$, David R. Cole ${ }^{5}$, Yousif K. Kharaka ${ }^{6}$, Timothy J. Kneafsey ${ }^{7}$, Kitty L. Milliken ${ }^{8}$, Laura J. Pyrak-Nolte ${ }^{9}$, and Roberto Suarez-Rivera ${ }^{10}$ 
Fine-grained sedimentary rocks - namely mudrocks, including their laminated fissile variety shales - make up about two thirds of all sedimentary rocks in the Earth's crust and a quarter of the continental land mass. Organic-rich shales and mudstones are the source rocks and reservoirs for conventional and unconventional hydrocarbon resources. Mudrocks are relied upon as natural barriers for geological carbon storage and nuclear waste disposal. Consideration of mudrock multi-scale physics and multi-scale spatial and temporal behavior is vital to address emergent phenomena in shale formations perturbed by engineering activities. Unique physical characteristics of shales arise as a result of their layered and highly heterogeneous and anisotropic nature, low permeability fabric, compositional complexity, and nano-scale confined chemical environments. Barriers of lexicon among geoscientists and engineers impede the development and use of conceptual models for the coupled thermal-hydraulic-mechanicalchemical-biological (THMCB) processes in mudrock formations. This manuscript reviews the THMCB process couplings, resulting emergent behavior, and key modeling approaches. We identify future research priorities, in particular fundamental knowledge gaps in understanding the phase behavior under nano-scale confinement, coupled chemo-mechanical effects on fractures, the interplay between physical and chemical processes and their rates, and issues of non-linearity and heterogeneity. We develop recommendations for future research and integrating multidisciplinary conceptual models for the coupled multi-scale multi-physics behavior of mudrocks.

52 Consistent conceptual models across disciplines are essential for predicting emergent processes 53 in the subsurface, such as self-focusing of flow, time-dependent deformation (creep), fracture 54 network development, and wellbore stability.

Keywords: mudrock, shale, coupled processes, hydraulic fracturing, diagenesis, spatial scale, 


\section{Introduction: Shale Architecture, Heterogeneity, and Coupled Processes}

\subsection{Significance of mudrocks, and laminated mudrocks - shales}

Sedimentary rock containing more than 50 percent (by weight or volume) of particles less than 62.5 microns in size are known variously as shale, siltstone, claystone, mudstone, and are cumulatively referred to as mudrocks ${ }^{[1-3]}$. Some workers apply "shale" narrowly to refer to the visibly laminated, fissile variety of this sedimentary rock, but in this paper we apply this term as the overall name for the broad class of fine-grained layered sedimentary rocks, and, where appropriate, use it interchangeably with the term "mudrock" ${ }^{[4]}$. Shale constitutes around twothirds of the sedimentary record of planet Earth ${ }^{[5,6]}$, and a quarter of the continental land mass

${ }^{\text {[7] }}$. In some portions of sedimentary basins, distant from the principal axes of sediment transport, the abundance of mudrocks may approach 90 percent of the local sediment volume ${ }^{[8]}$. Shales are volumetrically dominant in both marine and terrigenous successions, and host significant portions of the fluid-rock interactions controlling fate and transport of elements in the upper crust ${ }^{[9]}$, and atmosphere - e.g., chemical weathering of shale has been shown to serve as a long-term global sink for carbon dioxide $\left(\mathrm{CO}_{2}\right)^{[7]}$. Thus, shale properties are key controls on interactions of the atmosphere, hydrosphere and sedimentary lithosphere in many contexts, and are crucial reservoirs for unconventional oil and gas production, top seals for conventional hydrocarbon traps and geological $\mathrm{CO}_{2}$ storage (GCS), and isolation of nuclear and other high-level wastes.

In each case, shales are of interest both as barriers to fluid flow (seals) and as rock units that support flow of their contained fluids (reservoirs). Accelerated growth of information on Earth's most abundant sedimentary rock highlights key gaps in our understanding of this rock type. The development of conceptual models for the coupled thermal-hydraulic-mechanical-chemicalbiological (THMCB) processes in shale formations presents a major scientific challenge. In this paper we assess outstanding and fundamental issues in shale science that present obstacles to practical management of shales as seals, reservoirs, and source rocks. We develop recommendations for future research and integrating multi-disciplinary data for models appropriate for multi-scale, multi-physics coupled processes in shale. 
The physical and chemical properties of shales are controlled by their depositional environment, post-depositional diagenetic history, and engineering activities. In general terms, shales are commonly distinguished by their layered low-permeability fabric and composed of fine-grained minerals. One of the primary components of source rock shale is organic matter (e.g., kerogen). Porosity and pore sizes of shale are variable; however, nano-pores comprise a large fraction of the total porosity ${ }^{[10-13]}$.

102

Historically, shales have been strongly identified by their clay mineral content because clay minerals are a component that controls the physical behavior of shale at scales ranging from field and laboratory to the nano-scale ${ }^{[14]}$. Although most shales contain at least a few volume percent of clay minerals, petrographic inspection by high-resolution methods shows that nonphyllosilicate minerals such as quartz, feldspar, and calcite dominate in many shale lithologies and that organic components contribute additional complexity ${ }^{[15-17]}$. Compositional classification of shales has not, to date, benefited from a level of community consensus that is analogous to the widely applied classifications of sandstones and limestones ${ }^{[2,18,19]}$. It is clear however, that shales display a range of mineralogical compositions that encompass that of sandstones and limestones in addition to actual clay-mineral-rich rocks ${ }^{[2]}$.

Recent advances in understanding shale heterogeneity at many scales have been founded, in part, on a heightened appreciation of the nature of fundamental components (grains, cements, and grain replacements) as revealed by high resolution electron microbeam imaging ${ }^{[20]}$. Both observational ${ }^{[18]}$ and experimental ${ }^{[21]}$ approaches demonstrate that the physical sedimentology of fine-grained sediments entails a complex set of advective transport mechanisms as well as gravity settling, leading to distinctive textural and fabric characteristics at the bed scale that can be used to infer depositional conditions ${ }^{[18]}$. In this paper we use the term "texture" (rock microstructure) to refer to the combination of properties, including maturity, pore characteristics,

122 fragment shape, roughness, composition, sorting, and diagenetic features - matrix and cement $123[22]$. 
125 Pores in shale manifest at a variety of sizes within kerogen (organic material), the inorganic

126 mineral matrix, and fractures formed during natural processes or engineering activities ${ }^{[23,24]}$.

127 The structures of pores reflect depositional processes and also the chemical and mechanical

128 diagenetic processes associated with burial. In organic-rich shales, thermal maturation results in

129 kerogen cracking and production of liquid hydrocarbons and gas, which also modifies the nature

130 of porosity within organic components associated with these rocks.

131

132 Pore waters comprise approximately 20 percent by volume of most sedimentary basins ${ }^{[25,26]}$.

133 The salinity of pore waters in petroleum reservoir rocks, including values reported for shale and

134 tight reservoirs with in situ temperatures of $\sim 20-150{ }^{\circ} \mathrm{C}$ and fluid pressures of $\sim 100-1,000$ bar,

135 varies widely from approximately $1,000 \mathrm{mg} \mathrm{L}^{-1}$ to over $400,000 \mathrm{mg} \mathrm{L}^{-1}$ total dissolved solids

136 (TDS) ${ }^{[26]}$. Detailed inorganic and organic chemical analyses, together with measurements of

137 stable and radioactive water and solute isotopes have shown that the formation waters in

138 sedimentary basins are dominantly of local meteoric or marine connate origin. However, bittern -

139 residual evaporated seawater, geologically old meteoric water, and especially waters of mixed

140 origin are important components in most sedimentary basins ${ }^{[26]}$. During diagenesis, the original

141 waters of deposition evolve to $\mathrm{Na}-\mathrm{Cl}, \mathrm{Na}-\mathrm{Cl}-\mathrm{CH}_{3} \mathrm{COO}-$, or $\mathrm{Na}-\mathrm{Ca}-\mathrm{Cl}$-type waters by a

142 combination of several processes including (1) dissolution of evaporites, especially halite; (2)

143 diffusion and advection, especially in and near salt domes; (3) reflux and incorporation of

144 bitterns; (4) dissolution, precipitation and transformation of minerals other than evaporites; (5)

145 interaction with clay minerals, principally mudrocks (and shales) behave as geologic membranes

146 and have high ion exchange capacities; (6) interactions with organics, including petroleum and

147 solid organic matter, as well as bacteria that can survive in sedimentary basins at temperatures of

148 up to $\sim 80^{\circ} \mathrm{C}$; and (7) mixing of different waters. The important processes responsible for the

149 chemical evolution of water in each basin can be identified using chemical markers and isotopic

150 tracers ${ }^{[26-30]}$.

151

152 The significant compositional and textural heterogeneity that arises from the integrated effects of

153 depositional, biologic, and diagenetic processes in shales is observed on the scale of nanometers

$154{ }^{[31,32]}$ to meters ${ }^{[18]}$ to kilometers. Methods to honor this multi-scale heterogeneity in models that 
155 predict the response of shales to natural and induced physical and chemical changes is one of the 156 key challenges of shale science.

\subsection{Why is THMCB process coupling important for shale?}

The compositional and textural complexity of shale (Figure 1) is manifested in non-linear progression of physical and chemical processes, and hard-to-predict response to natural and anthropogenic perturbations. The time-dependence and the interplay of chemical, mechanical, and transport processes have been directly observed, in particular in engineered systems. These coupled processes develop in highly nonlinear fashion and can range across length scales from nanometers to kilometers (Figure 1), and across time scales from geological time scale to nanoseconds. The two-way process coupling in shale is presented in Table 1. There are numerous unknowns about how THCMB processes in shale are coupled and at what spatial and temporal 168 scales.

\section{Figure 1.}

Table 1.

Diagenesis is one of the classic examples of process coupling in shale. A volumetrically important diagenetic reaction is the transformation of mixed layer clays (MLC), containing smectite layers, to MLCs containing increasing proportions of illite ${ }^{[33]}$. This diagenetic reaction

177 is often accompanied by a volume change and is the source of significant dissolved silica that

178 results in quartz cementation of proximal reservoir sands ${ }^{[34,35]}$, and possibly, the shales

179 themselves ${ }^{[36]}$. This reaction also produces significant volumes of water that can cause the 180 development of geologic overpressures ${ }^{[37,38]}$. The absolute value of volume change during the 181 transformation of smectite to illite is not a constant, and depends on the chemical pathway.

182 Osborne and Swarbrick (1999) calculated the volume change associated with 10 possible 183 smectite to illite reaction pathways ${ }^{[39]}$. The volume change ranges from an increase of $4.1 \%$ to a 184 decrease of $8.4 \%$ depending on reactants and products (see also ${ }^{[40]}$ ). A positive volume change 185 and developed overpressure may cause a decrease of horizontal stress and induce fracturing in 
cases where the fluid pressures exceed the local minimum principal stress. Shale fracturing takes place anisotropically, resulting in irreversible changes in shale fabric ${ }^{[41]}$, and increases, also anisotropically, the permeability by orders of magnitude. Shale architecture shaped by diagenesis controls the preferential flow across scales.

As indicated by Dusseault, 2004, shale is the only "common" rock type, where all four (Darcian, Fickian, Fourier and Ohmic) diffusion processes can co-exist as processes of first-order importance ${ }^{[42]}$. Presence of the nano-channel and nano-pore structures in shale, as well as mixed wettability (e.g. water- and oil-wetting) networks control transport behavior ${ }^{[43]}$, while reactive transport in turn affects the pore structures ${ }^{[44,45]}$. Additionally, the combined effects of high salt content and large proportion of water bound at interfaces (water films) relative to free water, result in the overall low chemical potential (limited activity) of water, and chemical behavior differing from the bulk-phase behavior.

In coupled processes, observed in shale formations, one of the key variables is volume change ${ }^{[39,}$ ${ }^{40]}$. Microscopic processes of swelling and shrinking of clay minerals results in macroscopically observed expansion and contraction of shale beds. Volume changes control the state of stress, which leads to yield (shearing and fracturing) and changes in geometry of pore and fracture networks, and resulting changes in permeability and diffusivity ${ }^{[44]}$. Understanding the THCMB process coupling and feedbacks necessitates quantifying the volume changes, governing processes and their rates and incorporating them into numerical models.

Chemical controls on fractures are common for various rock types, including shale. Most commonly, chemically-induced fracturing in shale is due to (1) cation-exchange reactions involving swelling clay minerals, which may result in positive or negative volume change ${ }^{[42]},(2)$ mineral phase transformations, also resulting in volume change, and (3) chemical weakening of the silica- or metal-oxygen bonds due to the chemical attack (by water, proton or hydroxyl) on the accessible substrates - mineral grain surfaces and cements - contributing to fracture initiation and growth ${ }^{[46]}$. 
In some cases, biologic interactions in fine-grained systems can be profound ${ }^{[31,32,47]}$. They are, however, limited by the "tightness" of the rocks: it has been shown that in shale with pore throat sizes less than 0.2 micron, biological activity is limited ${ }^{[48]}$. However, in perturbed shale systems - for example, in gas wells in the Barnett shale - significant biological activity, manifested as biogenic sulfide production and microbially-induced corrosion, have been documented ${ }^{[49]}$. These introduced microorganisms in oil and gas fields can cause reservoir plugging, decline in the resource quality, and corrosion of metal-containing equipment ${ }^{[49]}$.

Coupled THCMB processes in engineered, or perturbed, systems are of particular interest in various applications ranging from wellbore stability, to performance of geological $\mathrm{CO}_{2}$ storage reservoirs, and repositories for used nuclear fuel (UNF). In these applications, removal (oil and gas production, construction of wellbores or underground repository shafts) or emplacement $\left(\mathrm{CO}_{2}\right.$, nuclear waste packages) of materials interfere with the original either true or pseudosteady-state, or, local equilibrium conditions of the system. For example, when $\mathrm{CO}_{2}$ is injected into a geologic formation, some of the $\mathrm{CO}_{2}$ dissolves in the pore brine and forms carbonic acid, lowering the brine $\mathrm{pH}$, initiating geochemical re-equilibration through mineral dissolution and re-precipitation ${ }^{[50,51]}$. Other examples of process coupling during engineering activities are: (1) when a stainless steel UNF waste package is placed in a repository, gas generation from the canister corrosion can cause fracturing of the porous media, contributing to the positive feedback loop in the coupled fracture-transport ${ }^{[52]}$; and (2) borehole instability, which has been observed for both smectite-rich shales with porosities in excess of 10\%, as well as in low-porosity (less than $10 \%$ ), highly fractured, quartz/illite-rich shale ${ }^{[42]}$. These types of shale are common and are encountered in most deep drilling operations. The borehole instability is largely attributed to process coupling - when volume is added or withdrawn as occurs with swelling clay minerals in smectite-rich shale, the state of stress around the borehole is modified, creating the potential for further yield, channeling and dilation ${ }^{[53]}$. The dynamic volumetric dilation is manifested all the way to the processes occurring at the pore throats ${ }^{[53]}$.

Quantitative predictive models are limited and still under development due to the complexity of coupled processes and their manifestations over the large range of length and temporal scales. The contemporary challenge is to understand process couplings and emergent phenomena such 
247 as preferential flow path development, time-dependent deformation, fracture network

248 development, and wellbore stability across spatial and temporal scales in natural as well as in

249 perturbed systems. We suggest that the complexity of the THCMB process coupling in shale

250 requires a systematic approach involving a broad range of disciplines. This systematic approach

251 could create a foundation for a common language that could be used by the various disciplines

252 that study or engineer shale. In the following sections we review the state-of-the-art

253 methodologies used to address key subsets of coupled processes across the THCMB spectrum.

\section{Methods}

The selection of primary literature for this systematic review was based on whether the full range or any combination of the THCMB coupled processed is specifically addressed. Given the multiscale multi-process nature of this review, we included both experimental, field, and theoretical studies. Only literature in English is included. We have identified the physical, chemical, mechanical, and geological properties of shale that distinguish it from other rock types. We reviewed the methodologies developed to address process coupling at various time and length scales, and synthesized the data to outline recommendations for future research on coupled

264 processes and data integration.

\section{Methodologies Applied to Coupled Processes in Shale}

\subsection{Post-depositional physical and chemical processes in shale (diagenesis)}

Post-depositional changes cause further heterogeneity in fine-grained sediments and encompass a

271 similar range of chemical and mechanical processes as are observed in the diagenesis of other

272 sedimentary rocks. Compaction ${ }^{[25,54]}$, cementation by carbonate, quartz, and other minerals ${ }^{[45]}$,

273 pressure solution ${ }^{[55]}$, and grain replacement such as albitization of feldspars ${ }^{[56]}$ are all observed

274 in shales. The details of these processes in mudrocks are, however, still poorly understood

275 compared to similar processes observed in sandstones and limestones. 
277 The transformation of smectite layers in MLC with increasing temperature is the key diagenetic

278 reaction in shale in sedimentary basins, including the northern Gulf of Mexico basin ${ }^{[26,35,57]}$.

279 Due to the large volumes of clay minerals, the water and solutes released and consumed by the

280 MLC transformation are major factors shaping the hydrogeochemistry and petroleum resources

281 of these basins ${ }^{[35]}$. Several incongruent reactions conserving aluminum (Al) or maintaining a

282 constant total volume have been proposed for this transformation ${ }^{[38,57]}$. The reaction of Equation

$2831^{[26]}$ conserving both $\mathrm{Al}$ and $\mathrm{Mg}$, and precipitating chlorite, quartz, and illite is probably a closer

284 approximation based on the composition of formation water observed in the northern Gulf of

285 Mexico basin.

286

287

288

$10.8 \mathrm{H}^{+}+3.81 \mathrm{~K}^{+}+1.69 \mathrm{KNaCa}_{2} \mathrm{Mg}_{4} \mathrm{Fe}_{4} \mathrm{Al}_{14} \mathrm{Si}_{36} \mathrm{O}_{100}(\mathrm{OH})_{20} \bullet 10 \mathrm{H}_{20} \Leftrightarrow$

289

$\mathrm{K}_{5.5} \mathrm{Mg}_{2} \mathrm{Fe}_{1.5} \mathrm{Al}_{22} \mathrm{Si}_{35} \mathrm{O}_{100}(\mathrm{OH})_{20}+1.59 \mathrm{Mg}_{3} \mathrm{Fe}_{2} \mathrm{AlSi}_{3} \mathrm{O}_{10}(\mathrm{OH})_{8}+$

$24.4 \mathrm{SiO}_{2(\mathrm{~s})}+22.8 \mathrm{H}_{2} \mathrm{O}+1.69 \mathrm{Na}^{+}+3.38 \mathrm{Ca}^{2+}+2.06 \mathrm{Fe}^{3+}$

290

291

Ferric iron $\left(\mathrm{Fe}^{3+}\right)$ in reaction (1) will be reduced by organic matter to $\mathrm{Fe}^{2+}$ and some may

292 precipitate as pyrite or ankerite. The overall reaction consumes large amounts of potassium $\left(\mathrm{K}^{+}\right)$

293 and protons $\left(\mathrm{H}^{+}\right)$and adds calcium $\left(\mathrm{Ca}^{2+}\right)$, sodium $\left(\mathrm{Na}^{+}\right)$and some iron $\left(\mathrm{Fe}^{2+}\right)$ to the pore water.

294

295

Diagenetic illite and quartz are also the major pore-occluding cements in the petroleum

296 reservoirs of North Sea ${ }^{[58]}$ and Saudi Arabia ${ }^{[59]}$. Illite and quartz in these basins are formed from

297 reactions of K-feldspar and kaolinite as depicted in reaction (2). Illitization of existing kaolinite

298 is postulated to occur isochemically at a threshold temperature of $\sim 140^{\circ} \mathrm{C}{ }^{[58]}$.

299

300

$\mathrm{KAlSi}_{3} \mathrm{O}_{8}+\mathrm{Al}_{2} \mathrm{Si}_{2} \mathrm{O}_{5}(\mathrm{OH})_{4} \Leftrightarrow \mathrm{KAl}_{3} \mathrm{Si}_{3} \mathrm{O}_{10}(\mathrm{OH})_{2}+2 \mathrm{SiO}_{2(\mathrm{~s})}+\mathrm{H}_{2} \mathrm{O}$

301

302 As detailed in Kharaka et al. ${ }^{[60]}$, the salinity and chemical and isotopic compositions of pore

303 waters from conventional and unconventional reservoirs from the same basin/sub-basin and

304 pressure and temperature conditions appear comparable, indicating that diagenetic pathways

305 experienced by fine-grained sediments are similar to the processes in coarser sediments ${ }^{[61,62]}$. 
Basin modeling and basin petroleum system modeling (BPSM) represent integrated approaches to recreate the diagenetic evolution of sedimentary basins, the latter focusing explicitly on hydrocarbon systems ${ }^{[63]}$. The traditional goal of BPSM is to quantify the history of hydrocarbons in conventional reservoirs for exploration and resource extraction by reconstructing and/or incorporating the original hydrocarbon source location, generation, expulsion, migration pathways and preservation in hydrocarbon traps ${ }^{[63]}$. Original sediment deposition and subsequent diagenetic processes integrated by BPSM can include: sediment depositional environments, sediment types and structures, sedimentation rates, compaction, cementation, thermal history, dewatering and porosity evolution, kerogen maturation, hydrocarbon generation-migration-accumulation, multi-phase flow including relative permeability, capillary pressure, and assumptions on wettability, phase behavior of hydrocarbons and/or other fluids, pore pressure evolution, (effective) stress changes, and faulting. The BPSM approach can be applied spatially in 1, 2, or 3 dimensions. Major differences of BPSM from typical conventional reservoir modeling include large basin-scale domains (on the order of hundreds of kilometers with large grid block sizes in the numerical modeling) and geologic time scales (e.g., hundreds of millions of years) as opposed to meter or kilometer scale modeling over months to years ${ }^{[63]}$.

Application of BPSM to shale hydrocarbon plays is relatively new and still under development. Recent effort focuses on treating the shale play as both source and reservoir. Romero-Sarmiento et al. (2013, pages 315-316) explain that "expelled [hydrocarbons] have been therefore used as a parameter to adjust for the assessment of conventional petroleum systems ${ }^{[64]}$. A thorough simulation of expulsion and retention mechanisms was not therefore necessary to define conventional oil and gas in place in the reservoirs." Romero-Sarmiento et al. (2013) present approaches for basin-scale shale-play BPSM that include: source-rock kinetics, chemical transformations, and evolution of total organic carbon (TOC) and associated porosity, retention of hydrocarbon fluids (e.g., via sorption or as a free-phase in kerogen porosity), and assumptions of porosity evolution of kerogen-hosted pores versus mineral matrix pores (e.g mineralassemblage-hosted pores respond to stress state whereas organic pores respond mainly as a function of maturity i.e., thermal history) ${ }^{[62]}$. Recent and developing knowledge of the phase behavior of hydrocarbon fluids under nano-scale confinement, non-Darcy transport process (e.g., 
Knudsen transport), complex cementation/dissolution textures, and creep and other mechanical responses still need to be fully integrated in shale BPSM to enable better estimates of hydrocarbon resources in place and their exploitation potential.

\subsection{Physical and chemical controls on fracturing in shale}

As discussed above, the heterogeneous nature of organic-rich shales arises from textural complexity and variation in mineralogical composition. Fractures and coupled processes in shales cannot be properly understood without accounting for the role of these textural/compositional variations in controlling the mechanical properties, failure and the interactions among rock deformation, pore pressure, fluid flow and solid-liquid geochemistry ${ }^{[41]}$.

The laminated nature and varying mineral/chemical composition of shale has been observed on multiple scales: from geologic observations at outcrops, in cores from organic-rich mudrock reservoirs, and from laboratory test (with $\mathrm{cm}$-resolution) that measure properties along the core length (Figures 2 and 3). Core measurements have shown that variation in mechanical properties of shale occur over intervals that range in scale from sub-centimeter to decimeters (Figure 3). For example, unconfined strength in a single shale core can range from $69 \mathrm{MPa}$ to $241 \mathrm{MPa}(10,000$ psi to 35,000 psi) among laminae, while Young Modulus has been observed to range from $7 \mathrm{GPa}$ to $34 \mathrm{GPa}$ (1 Mpsi to $5 \mathrm{Mpsi}$ ) on the same length scale (unpublished data). Equally large ranges of values of other mechanical properties are commonly observed ${ }^{[65]}$. Pervasive $\mathrm{mm}$ - to $\mathrm{cm}$ - to decimeter- scale layering with sharply contrasting properties is abundant (Figure 2). Large scale layering, on the order of meters, is also common and is caused by the presence of carbonate benches, or other mineral concentrations, and intercalated shale units (Figure 3). The sharply changing properties between thin rock units and the stacked rock architecture of organic-rich shales also results in the presence and distribution of weak interfaces with specific orientations (often bed parallel) which also affect fluid mobility and fracture propagation. Some of these interfaces were activated, parted, and/or mineralized, during basin development. Other interfaces are susceptible to slip when stresses and/or pore pressure change during drilling, hydraulic fracturing, production, as well as from associated regional changes in stress and deformation. For example, stresses and fluid pressure can vary widely in regions with a high density of wells 
where large volume of fluids are pumped in during hydraulic fracturing, and withdrawn during production. The presence of layering and weak interfaces results in preferential directions of deformation, failure, and fluid flow. Often these observed preferential directions do not align as predicted by simple homogeneous isotropic models.

\section{Figure 2.}

\section{Figure 3.}

These challenges have been clear to the mining and civil engineering industries, and their workflows and models include orientations and modes of rock failure that are controlled primarily by the presence, distributions, and properties of fault sets and discontinuities (i.e., planes of weakness). The role of the intrinsic rock properties on failure is proposed to be of secondary importance. Block Theory ${ }^{[66]}$ is an example of a methodology developed to understand and predict rock failure and excavation stability based on a detailed mapping of the orientation and distribution of planes of weakness in the regional rock system. Admittedly the mining and civil engineering industries focus predominantly on "stronger" rocks, where the intrinsic rock strength is larger than the shear strength of faults or other planes of weakness; and the confining stresses may be lower because of the shallower nature of their applications. Nevertheless, in contrast, the method and models the oil industry uses for rock deformation and failure (e.g., wellbore stability, hydraulic fracturing, depletion-induced compaction, and others), are primarily dependent on the intrinsic, homogenized, rock properties. These are typically obtained or predicted at well-log resolution (averaged over $2 \mathrm{ft}(60 \mathrm{~cm})$, Table 2) and, as a consequence, this minimizes or removes the representation of existing thin layering and interfaces - e.g. micron-scale fractures (Figure 4). Such a method may be appropriate and successful for conventional reservoirs, but is limiting for unconventional, over pressured, heterogeneous, anisotropic reservoirs. Regarding hydraulic fracturing, for example, it is now accepted that the layered nature of mudrocks and the ubiquitous presence of planes of weakness in them (often bed parallel) give rise to complex hydraulic fracturing geometries, the presence of multiple branches of fracture propagation, fish-bone structures of fracturing and leak off, step 
overs, and other geometric effects that do not occur in homogeneous isotropic materials and cannot be explained using homogeneous models (Figure 5) ${ }^{[67]}$.

\section{Figure 4.}

\section{Figure 5.}

Table 2.

Elastic or seismic wave characterization is often used to determine the mechanical properties of rocks in the subsurface from measurements of wave attenuation and velocity. However, interpretation of geophysical signals is complicated for shale because of the potential for competing sources of anisotropy: textural versus structural. Textural anisotropy arises from laminae, thin parallel layers of alternating composition and moduli (e.g. carbonaceous, silty, dolomitic, clayey, or lithoclastic) that range in scale from micrometers to centimeters, to decimeters (Figures 1, 2 and 3), and with orientations that depend on the original depositional environment and post-depositional tectonic processes. Structural anisotropy arises from microcracks, fractures, joints, and the aforementioned interfaces that range in scale from micrometers to meters, are sensitive to stress, and have orientations and spacings that may or may not align with the textural features based on the diagenetic and tectonic history or any activities that perturb the subsurface system. These competing sources of anisotropy can mask either the presence of fractures and/or the matrix/fabric anisotropy depending on the state of stress (i.e., stress magnitude and orientation).

The effect of competing anisotropy has been clearly demonstrated in the laboratory measurements on manufactured anisotropic medium. The acoustic wavefronts (Figure 6) were propagated through this anisotropic medium with fractures perpendicular to subwavelength layering ${ }^{[68]}$. The unique symmetry axis for the fracture set is vertical while that for the matrix is horizontal. In Figure 6, the spatial distribution of energy is shown at a fixed arrival time. At low or high stress, the measured anisotropy is controlled by either the fracture orientation or the matrix texture, respectively. However, at an intermediate stress, the fractured anisotropic 
medium appears isotropic as indicated by the circular shape of the wavefronts, i.e. the energy spreads out nearly uniformly in all directions. Interpreting rheological properties from velocities measured under the condition of the intermediate stress state would, incorrectly, yield isotropic moduli.

\section{Figure 6.}

Thus a question arises whether competing sources of anisotropy in fractured shale can be delineated using seismic or elastic wave techniques. Fractures and other mechanical discontinuities often give rise to converted-, guided- and scattered modes that could be used to interpret fracture and matrix properties. For example, the velocity of waves guided between or along fractures has shown promise as potential tool to extract both fracture and matrix properties from elastic waves. These guided modes depend on the orientation of a fracture relative to layering, the matrix and fracture mechanical properties, layer/fracture spacing and signal frequency ${ }^{[69,70]}$. Heterogeneity leads to scaling complexities that are the undeniable challenge for evaluating and modeling failure, fracture, and fluid mobility behavior of organic-rich mudrocks, for understanding their coupled effects, and for defining the type of measurements that will be relevant. Additional research is needed to assess the contributions to the scattered wave field not only from fractures but also from fracture intersections, fracture sets, stress gradients and fluids in order to characterize dynamically evolving fractured shale systems. This future research will determine whether competing sources of anisotropy are separable, if the dominant symmetry axis depends on stress and fluid conditions, and if the dominant symmetry axis also indicates fluid flow anisotropy.

The ability to detect and monitor the dynamic evolution of fractured shale systems using geophysical methods requires a link between a remotely-measured geophysical response and a characteristic property (or properties) of a fracture. For over two decades, several researchers have demonstrated that fracture-specific stiffness can be estimated from seismic wave attenuation and velocity ${ }^{[71-80]}$. The dependence of specific stiffness on the spatial and probability distribution of regions of contact between two fracture surfaces creates an implicit link to the hydraulic properties of a fracture through the fracture geometry ${ }^{[81,82]}$. Recently, Petrovitch et al. 
$461(2013,2014)$ determined the existence of a scaling relationship between fracture specific

462 stiffness and fluid flow for single fractures ${ }^{[83,84]}$. The numerical flow-stiffness data, simulated at

463 multiple length scales, collapsed to a single scaling function because fracture specific stiffness

464 captures the deformed fracture void topology that includes both changes in contact area and

465 aperture caused by stress as well as by transport-dominated chemical erosion ${ }^{[85]}$.

466

467 The resulting hydro-mechanical scaling function potentially provides a link between fluid flow

468 and the seismic response of a fracture, because fracture-specific stiffness affects seismic wave

469 attenuation and velocity. However, several outstanding questions related to the deformation of

470 fractures in shale and the scattered wave field must be addressed before extending these concepts

471 from single fractures to fracture networks in subsurface shale. For example: does a viscoelastic

472 matrix affect deformation of fracture void geometry in a manner that differs from pure elastic

473 conditions? Will the flow-stiffness relationship hold for partially-mineralized fractures that are

474 often found in shale? Can seismic data differentiate or unravel chemical, fluid and stress

475 alteration of fractures? Can scattered wave fields delineate the effects of stress gradients that lead

476 to non-uniform fracture topology and fluid distributions that mask or promote additional

477 scattering? And how do proppants or geochemically induced reaction halos affect fracture

478 deformation and in turn fracture specific stiffness?

479

480 The importance of the chemical effects on subsurface fracture behavior, or chemo-mechanical

481 coupling, has been recognized for several decades. Chemically assisted subcritical fracture

482 growth, also referred to as stress corrosion cracking, is proposed to control the time and

483 deformation-rate-dependent failure of rocks (e.g., ${ }^{[86-88]}$ and references therein). Resistance to

484 subcritical fracturing depends on microstructural heterogeneities: micro-fractures, grain

485 boundary cohesion and orientation, and mismatches in elastic properties between phases.

486 Development of large fracture populations and fracture architecture is controlled by chemical

487 processes in the micro-scale near-tip fracture regions ${ }^{\left[{ }^{[8-91]}\right.}$. In aqueous fluids, mineral reactions

488 have been shown to play a key role in subcritical fracture development at both bulk and

489 microscopic scales. 
491 A technique traditionally used for assessing reaction kinetic effects on subcritical fracture

492 propagation is double-torsion geomechanical testing, which allows measuring fracture

493 propagation rate and subcritical index in shale under controlled fluid composition and

494 temperature ${ }^{[88]}$. A novel approach for interrogating coupled chemical-mechanical fracture

495 processes is X-ray computed tomography (CT) for imaging fractures while controlling stress

496 conditions using a triaxial cell. This technique enables characterization of fracture formation and

497 permeability changes at in situ temperature, pressure and stress conditions ${ }^{[92]}$. The CT data can

498 be used as model input ${ }^{[92,93]}$ enabling prediction of fracture behavior as a function of fluid

499 pressure and changes of in situ stress. The accuracy of these models depends on the proper

500 inclusion of interfaces and fluid flow processes.

501

502 Further development of coupled models is needed in order to predict coupled fracture, multi-

503 phase flow, and multi-component reactive transport in the subsurface, and to capture the effect of

504 geochemical reactions on fracture permeability. These new models require that the solid solvers

505 are coupled to the multi-phase reactive flow and reactive transport codes. One difficulty in

506 modeling chemical-mechanical processes in shale, is that a model must incorporate changes in

507 volume that correspond to changes in chemical concentration which in turn are coupled to the

508 diffusion processes. In addition, laboratory data to support or verify such models is sparse.

509

$510 \quad 3.3 \quad$ Fluid flow in multi-porosity systems

511

512 Fluid flow in shales takes place in a variety of void or pore structures. Salient features that

513 influence flow and transport include: the occurrence of discrete pore networks within kerogen

514 and inorganic components (e.g., clay and silt), that have different wettabilities and characteristic

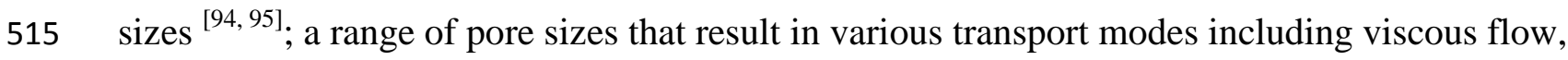

516 Knudsen flow, transition flow (viscous and Knudsen flow), and diffusive fluxes encompassing

517 ordinary Fickian diffusion including effect of mass (Graham's Law), and adsorption-desorption

518 processes on the surface of pores of the minerals or organic matter ${ }^{[96]}$; a variety of pore body and

519 throat shapes, sizes, and topologies that can strongly affect multi-phase flow processes such as

520 imbibition-drainage (Figure 7), especially relevant for liquid and gas hydrocarbon systems ${ }^{\text {[97]; a }}$

521 vast range of natural or induced fracture types that reflect paleo and recent fluid flow, and 
522 precipitation-dissolution that may have modified the porous matrix or fracture permeability

523 (Figure 4). Different flow mechanisms can occur for different scales of the pore structures ${ }^{[98]}$.

524 The orientation of fractures (or faults) relative to the current regional and local stress regime can

525 affect whether the fractures-faults are critically-stressed and "hydraulically active."

526

527 Additional complexity is introduced by the large variability of the organic matter associated with

528 shale ${ }^{[44,99]}$. For example, laboratory measurements of hydrocarbon fluid extraction and

529 composition indicate measurable differences in hydrocarbon compositions and in the partition

530 between light components, intermediate molecular weight components and heavy components,

531 within short intervals in the same formations and at the same levels of thermal maturity ${ }^{[100]}$. This

532 is most likely due to the heterogeneous distribution of macerals in the system and also to the

533 effect of rock texture and composition on moderating the thermal processes of hydrocarbon

534 generation and cracking. Thus fluid separation (oil and water) in relation to surface energies

535 (mineral and organic surfaces), and changes in hydrocarbon composition in relation to changes in

536 rock texture and composition are factors that also contribute to the heterogeneous distribution of

537 pore pressures, and control the flow in the system.

Figure 7.

541 The large variety of pore types ${ }^{[44]}$, many of which can occur in a shale formation at a range of

542 scales, makes the quantification and/or prediction of flow and transport difficult. Current

543 techniques for understanding the transport in the multi-porosity shale system include a

544 combination of methods to characterize the pores and model flow and transport. Several studies

545 use fully three-dimensional (3D) imaging or serial sectioning to characterize the pores and then

546 reconstruct digital models of the pore geometry and connectivity of solid components. Primary

547 methods (Table 2) include dual beam focused ion beam-scanning electron microscopy (FIB-

548 SEM) (Figure 7), X-ray CT and micro- to nano-tomography, and neutron tomography, with

549 resolutions from $\sim 1 \mathrm{~nm}$ to 10 s of microns or higher for medical X-ray CT systems ${ }^{[24]}$. A major

550 concern of reconstructions for flow modeling is whether the small volumes representative of the

551 digital reconstructions are representative of bulk volume properties of the shale. These volumes

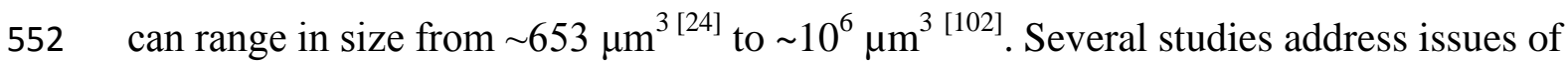


representative elementary volume (REV) to determine the length scale at which shale properties become statistically stable and suited for modeling by continuum methods ${ }^{[24,103-105]}$. It appears porosity REVs can be obtained for some shales from FIB-SEM 3D reconstructions: e.g., members of the Bakken, ${ }^{[24]}$; however, it is not possible to obtain an REV for permeability for the same study because the FIB-SEM volumes are too small. Rui et al. $2016^{[106]}$, have recently presented a scaling up approach predicting kerogen REV using a nanopore-network modeling, and predicted an REV of $5 \mu \mathrm{m}^{3}$ (Figure 8). Establishing the ranges of sizes for REVs in kerogen, clay mineral-rich components, and mixtures of these with larger grains has not yet been fully investigated; however, and limited data is available to determine if REVs for certain shale lithotypes can be universally applicable to other shales (or even regions within the same shale). The unique depositional and diagenetic histories may make it difficult to determine which REV length scales are appropriate for different shale lithofacies. Concepts of representative elementary time (RET) also come into play for the given process under study, as the different pore types have different characteristic length scales that in turn affect the characteristic time scales of processes ${ }^{[44]}$. Other studies address transport through laboratory measurements of permeability, porosity (connected and disconnected), capillary breakthrough pressure, wettability, and fracture hydraulic aperture and conductance ${ }^{[54,96]}$. Laboratory petrophysical properties suffer from the limitations due to retrieval and handling of core, which may induce microcracks and fractures that are not present in the subsurface. Additionally, the variety of techniques can give disparate results, especially when compared to digital pore network reconstructions.

\section{Figure 8.}

Modeling approaches for pore-scale flow and transport in shale range from theoretical to empirical-either idealized pore body and throat sizes and connectivity are assumed or digital reconstructions from direct imaging are used ${ }^{[97,102]}$. Theoretical models typically capture laboratory-based behaviors such as drainage of a non-wetting phase and absolute permeability using network models such as bundle-of-tubes model; regular-lattice models; acyclic models; and multi-scale-multi-physics networks ${ }^{[97,98,107,108]}$. Theoretical models have revealed that certain pore structures can capture multi-phase transport behaviors such as the non-plateau 
584 drainage in shale ${ }^{[97]}$ and allow for estimation of fitting parameters that may be helpful for 585 classification of different shales. Empirical modeling using digital reconstructions from shale samples involve realistic pore structures, geometries, and topologies. Approaches include level

587 set methods, volume of fluid methods, gradient based computational fluid dynamics, and Lattice

588 Boltzmann (LB) methods. LB methods in particular show much potential for shale as they 589 capture pore geometries and can represent large differences in densities of two fluids occupying the pore space ${ }^{[93,109]}$. They also unfortunately suffer from the small REV problem discussed 591 previously.

Wasaki and Akkutlu proposed a matrix permeability model for organic-rich shale and considered 594 its coupling to a fracture during shale gas/oil production ${ }^{[110]}$. They argued that the shale 595 permeability is not a petrophysical quantity in the classical sense reflecting the fluid transmitting ability of the pore network but instead it is an overall mass transfer coefficient that needs to be

597 carefully tuned to honor the total mass flux of fluids draining into the fractures. They presented a 598 conceptual transport model for the shale matrix with dual-porosity and single-permeability 599 delineating the transport mechanisms at multiple-scales: (i) adsorption and diffusion mainly in 600 the kerogen pores; and (ii) diffusion and convection in micro-cracks and other slit-shape 601 inorganic pores.

602

604

$\mathbf{k}_{\mathrm{gas}}=\mathbf{k}_{\mathbf{m}}+\mu c_{g} D \mathbf{I}+\mu \frac{V_{s L} \rho_{\text {grain }} B_{g}}{\varepsilon_{k s}} \frac{p_{L}}{\left(p+p_{L}\right)^{2}} D_{s} \mathbf{I}$

605

Here, I is second order identity matrix. Wasaki and Akkutlu (2015) recognized that the observed 607 anisotropy also exists in the flow field and inherently belongs to micro-cracks contribution $\left(\mathbf{k}_{\mathbf{m}}\right)$ 608 which is sensitive to effective stress (Figure 9). The authors gave analytical expressions for the 609 micro-crack permeability components, $\left\{\mathrm{k}_{\mathrm{m}}\right\}_{11},\left\{\mathrm{k}_{\mathrm{m}}\right\}_{12}$, and $\left\{\mathrm{k}_{\mathrm{m}}\right\}_{22}$. Accordingly, if horizontal 610 flow is considered, $\left\{\mathrm{k}_{\mathrm{m}}\right\}_{11}$ and $\left\{\mathrm{k}_{\mathrm{m}}\right\}_{12}$ are the elements that will affect the flow, and $\{\mathrm{km}\}_{12}$ can 611 be important if pressure gradient in vertical direction exists. Note that only the natural gas flow 612 has it non-Darcian effects, as shown in Equation 3b, due to presence of molecular transport 613 mechanisms taking place in the kerogen. These mechanisms are pore diffusion and cluster 
614 diffusion of the adsorbed molecules and here represented by the isotropic diffusion coefficients,

$615 D$, and $D_{s}$, respectively, following terminology presented by Akkutlu and Fathi (2012) ${ }^{[23]}$.

617 Figure 9.

619 At the production scale, another type of modeling - pressure transient or rate transient analysis 620 (PTA/RTA) - involves inversion of pressure and/or flow rate measurements at a production 621 wellhead to estimate reservoir transport parameters and properties. PTA/RTA methods can 622 represent the pore space as dual, triple, or multi-continua in order to attempt to capture the 623 multiple pore types and their interchange of fluids ${ }^{[111-113]}$. Reactive transport modeling (and 624 other geochemical modeling) can be used for mm- to reservoir scale systems and is commonly 625 applied to addresses mineral dissolution/precipitation, adsorption/desorption, and homogeneous 626 chemical reactions ${ }^{[114]}$.

627

628 Fluid flow in shale is often coupled to other physical and chemical processes, resulting in 629 coupled phenomena. These can include mechanical behavior where the shale behaves as a 630 partially-drained or undrained medium, thus affecting the mechanical constitutive behavior. 631 Distinct pore networks in kerogen or the inorganic clay-silt components can exhibit different 632 stiffness/compliance for different deviatoric stress and conditions of the pore fluids e.g., Biot and 633 Skempton coefficients ${ }^{[115]}$. Thus, the permeability of kerogen may be affected by flow and 634 compaction or other mechanical processes at time-scales different from the pore networks of the 635 inorganic components, which in turn affects the overall flow regimes in shale impacted by 636 natural or engineering activities. The texture of a shale can strongly affect flow due to matric 637 (combined effects of capillarity and adsorptive forces) and osmotic potentials-nano-scale 638 confinement affects the phase behavior e.g., mean free path of a gas molecule and hence 639 transport behaviors. Texture can cause flow mechanisms to be species-dependent as the mean 640 free path may vary due to pressure changes (Knudsen number can vary during production of a 641 reservoir). The ability to flow methane gas in a system with porosity dominated by kerogen642 matrix is also a function of the percolation threshold of the connected kerogen volume in any 643 given organic-rich shale system. 


\subsection{Nano-scale confinement, activity of water, and pore-scale coupled processes in shale}

Due to fine-grained shale fabric and presence of nano-pores, fluids (gas, oil, brine) in shales are often present as nano-scale thin films, and occupy nano- and submicron-scale pores ${ }^{[116-120]}$. The resulting interfacial areas (fluid-fluid, and mineral-fluid) are relatively large for the pore volume and therefore control chemical and transport behavior in shale. As shown below, the combined effect of surface strain and fluid confinement results in a unique (and, largely unknown) set of thermodynamic parameters, different from those observed in the bulk phase ${ }^{[121-124]}$. For example, molecular dynamic (MD) simulations reported by Phan et al. (2014; 2015) have shown that methane solubility in confined water may far exceed that in bulk systems, and the release of methane from kerogen nano-pores is controlled by the geometry and connectivity of these pores ${ }^{[125]}$. Methane solubility in confined water strongly depends on the confining material, with silica yielding the highest solubility followed by aluminum $\left(\mathrm{Al}_{2} \mathrm{O}_{3}\right)$ and magnesium $(\mathrm{MgO})$ oxides ${ }^{[126 \text {, }}$ 127]. Investigators looking into hydrocarbon behavior under confinement recorded confinement effects on phase behavior, and fluid properties ${ }^{[124,128-130]}$. Figure 10 shows the suppression effect of nanopores on the phase envelop of pure methane and pure n-butane. The asymmetry in the suppression of the phase diagrams - the greater gap between the bulk and confined fluid in the left-hand-side compared to the right-hand-side on the phase diagram, indicates the greater impact of confinement on the vapor branch than on the liquid branch.

\section{Figure 10.}

Cristancho et al. (2016) have recently quantified the impact of organic pore wall heterogeneities on the hydrocarbon fluid storage capacity of the pore using atomistic modeling and molecular simulations ${ }^{[131]}$. For the purpose of creating heterogeneity, they have considered organic (carbon) walls with deficiencies and with non-hydrocarbon atoms, such as nitrogen. Their results, shown in Figure 11, indicate that the measured excess amount due to confinement on the stored methane is most pronounced between 6.9-34.5 $\mathrm{MPa}(1,000-5,000 \mathrm{psi})$, which is the typical shale gas reservoir pressure range. The pore wall surface heterogeneities have the potential to impact storage depending on the type and level of heterogeneities. Among the investigated 
675 heterogeneities, nitrogen-doping at the pore walls is found to be the most influential. Both the

676 adsorbed and excess amount decreased with the nitrogen-doped pore wall surfaces (Figure 11).

677

678

679

680

681

682

683

684

685

686

687

688

689

690

691

692

693

694

695

696

697

698

699

700

701

702

703

704

705

\section{Figure 11.}

The dielectric constant of water decreases with increasing nano-scale confinement ${ }^{[132,133]}$, and this effect becomes more pronounced when the pore size approaches $<5 \mathrm{~nm}$. Molecular dynamics simulations quantify the dielectric constant of water to be about one half of its unconfined value when water is contained in a $12 \AA(1.2 \mathrm{~nm})$ pore ${ }^{[133]}$. Due to the decrease in the dielectric constant the equilibrium constant for the mineral surface protonation ( $\mathrm{pKa}$ ) change, ultimately changing the sorption behavior of the mineral surfaces. Bourg and Steefel (2012) calculated that the average $\mathrm{pKa}$ value of silanol surface sites in a $2 \mathrm{~nm}$ nanopore is $0.5 \mathrm{pH}$ units higher compared to unconfined surfaces ${ }^{[134]}$. Experiments indicate that in silica pores with $<5$ $\mathrm{nm}$ pore size, both the density and the surface tension of water decrease with decreasing pore size $^{[135]}$. Other examples of emergent chemical behavior due to nano-scale confinement include the decrease in the solvation energy of metal cations, which promotes the formation of innersphere adsorption complexes over outer-sphere ${ }^{[136,137]}$, enhanced solubility of gas in water ${ }^{[138]}$, enhanced adsorption ${ }^{[137,139,140]}$, and modified redox properties ${ }^{[141-143]}$. The nano-scale nature of the chemical environments in shale dictates the unique chemical transport and reactivity trends, in particular ion-selectivity and semi-permeable membrane behavior.

The nano-scale pore structure, mixed wettability, and multi-phase fluid conditions of shale have a strong effect on the disposition and movement of water, oil, and gas, which can all interfere with each other's movement. Quantitative measurements of shale samples by nuclear magnetic resonance (NMR) indicate that the amount of "free" water - water not structured by electrostatic forces - is largely variable for different shale samples, and does not correlate with the overall porosity ${ }^{[42]}$. For example, only about $5 \%$ of total water content is "free" in smectite-rich shale of $10-20 \%$ porosity (Pierre II shale from Wyoming), while 50\% of total interstitial water is "free" in the quartz-illite shale with the lower porosity of 6-8\% (Queenston Shale from Ontario) ${ }^{[42]}$. Surface-bound water is not likely to be oil wetting, thus oil migration through such pathways will require higher pressure. NMR measurements have also been used to demonstrate mixed 
wettability of source rock shale and for quantifying the water-wetting vs. oil-wetting porosity ${ }^{[144]}$. The resulting ratio of water (brine)-wetting to oil (dodecane)-wetting ranged from 0.34 to $2.93^{[144]}$. This indicates that surfaces are heterogeneously wet - some shale surfaces are waterwetting, while others are hydrocarbon wetting. Interfacial contact lines will tend to pin at locations where wettability changes, and additional pressure is required to cross these regions. Both adsorbed water and hydrocarbon will partially occlude the geometric area available for flow in nanopores affecting phase mobility ${ }^{[97,145]}$.

Water in shale is subject to a variety of forces that affect its potential energy state (relative to a reference state) as expressed by the total potential. The total potential of water incorporates the matric potential, the osmotic (or solute) potential, the pressure potential, and the gravitational potential ${ }^{[146]}$. Pressure and gravitational potentials are invoked for understanding fluid flow in conventional reservoirs and aquifers. In tight shales, Darcian flow may not take place due to the limiting pore throat size. Because the majority of water may be "structured"- - bound to the mineral surfaces - a threshold pressure gradient is required for advective transport to begin ${ }^{[42]}$. High osmotic pressures (1-2 MPa) develop since hydrated ion flux is impeded ${ }^{[42]}$. Figure 12 shows the predicted osmotic pressure in the clay mineral pores as a function of the distance from the hydraulic fracture surface ${ }^{[147]}$. Hydraulic conductivity of smectite-rich shales depends on specific mineral surface characteristics (e.g., mineral surface charge, the ionic composition of the interstitial water, and temperature ("structured" water layer thickness decreases with increasing temperature, causing an increase in hydraulic conductivity). Therefore, hydraulic conductivity of shale is not a unique function of the pore and throat geometry. The following sections address the importance of the matric and osmotic potentials in shale with regard to the following: spontaneous imbibition-drainage, adsorptive fluid films and ion, and solute transport in shale.

The matric potential expresses combined effects of capillarity and adsorptive forces of a porous medium ${ }^{[148]}$. Capillary forces arise due to a pressure difference related to the curvature of the interface between two immiscible fluids, as expressed by the Young-Laplace equation that incorporates the effects of the pore size, interfacial tension, and contact angle. The nanometerscale pore sizes and water-wet or intermediate-wet conditions for certain pore networks in shale lead to high capillary pressure that can become significant in comparison to pressure potentials. 
738 The features of shale that control the matric potential include the pore size, shape, and wettability. Many studies have been performed to examine the pore structures in shales $[12,116,117$, 149-154], with Desbois et al. (2009) classifying pores. Pore geometry imposes the first order control on the mobility of water. Smaller, triangular pores or flat narrow pores (on the scale of $10 \mathrm{~nm}$ ) have a tendency to imbibe water and spontaneously fill at a given water chemical potential compared to larger, circular pores ${ }^{[155]}$ in part because adsorptive films take up a substantial portion of the pore space ${ }^{[156]}$. "Corners" influence the curvature of the fluid-fluid interface and thus their geometry affects the amount of capillary-held water ${ }^{[156]}$. The matric potential is currently being cited to explain the field observation when only a small portion of the water injected during hydraulic fracturing returns to the wellbore (e.g. 30 $\pm 10 \%$ return, ${ }^{[157]}$ ). Gas shale systems typically have high thermal maturities with little to no smectite component left in the MLC (e.g. Marcellus and Haynesville shales). In the thermally mature systems only a fraction of injected water is recovered, due to the low chemical potential of water in these formations. In some cases, the observed return of injected water is higher: for examined wells in the Marcellus Shale, 10-50\% of the fracturing fluid returns to the surface as produced water after a year of production ${ }^{[62]}$; while for Barnett Shale, large variability from $<20 \%$ to $>350 \%$ in the ratios of returned to injection water are observed after 4 years of production ${ }^{[158]}$. The return in excess of $100 \%$ indicates that wells produce local waters from adjacent formations. Extensive petrophysical evaluation of gas-bearing shale systems shows them to have very low water saturations and essentially no free mobile water phase. The limited water activity in organic-rich shale and how it is controlled by thermal maturity is an example of a coupled process that

Osmotic, or solute potential, is defined as the potential of water molecules to move from a

762 hypotonic solution to a hypertonic solution across a semi-permeable membrane ${ }^{[148]}$. Osmotic

763 potential is a function of the gradient in solute concentration. Due to the nano-scale porosity and

764 the permanent negative charge on the surfaces of clay minerals, shale acts as an ion-selective 765 semi-permeable membrane, with apparent ion mobility differing from the bulk-solutions ${ }^{[159]}$. 766 Therefore, shale can be conceptualized and modeled as an ion-exchange membrane with fixed 767 charged sites along narrow pores ${ }^{[160]}$. During Fickian ion transfer waters of hydration are 
transported with the ions. Flow occurs by osmotic pressure, governed by gradient in chemical potential. Shale exhibits a non-ideal, or "leaky" membrane behavior, due to the heterogeneity in pore size and pore throat geometry, with wider pores increasing the overall permeability to solutes. High concentrations of solutes have been observed in flowback water from hydraulic fracturing operations, indicating higher concentrations in the subsurface reservoir than in the injected water. The presence of this high-salinity brine and injection of low salinity brine is expected to drive an osmotic flow ${ }^{[61,101,165]}$.

The effects of osmotic pressure have been observed during well completions. Water from introduced fluids is absorbed into shale due to the difference in osmotic potential between the pore waters and the drilling mud or fracturing fluid, causing sloughing of well walls ${ }^{[119,161-163]}$. These processes have been incorporated in a coupled mechanical-thermal-physico-chemical model ${ }^{[53]}$. To account for the driving force on fluid flow due to osmotic potential, osmotic pressure is explicitly included in the rock water potential. The gradient between the rock water potential and water potential in drilling mud (or, hydrofracturing fluid) is the driving force for pore fluid flow ${ }^{[53]}$.

\section{Figure 12.}

Because shales may exist under low water saturations (for both liquid and gas hydrocarbons), the strong capillary and adsorption potential results in spontaneous imbibition and potentially counterflow of hydrocarbons from the shale matrix ${ }^{[164,165]}$. Other researchers quantify water uptake in shales through imbibition experiments, while taking into account effects of rock texture, complex pore networks, interactions between hydrofracturing fluid and minerals, and changes in osmotic potential, with some studies accounting for how concurrent and countercurrent flow during water imbibition impacts liquid and gas hydrocarbon recovery ${ }^{[166]}$. Findings indicate that the connectivity of water-wet and oil-wet pathways may differ, which in turn affect water uptake and hydrocarbon expulsion ${ }^{[165,166]}$. Thus, the matric potential is a major driving force for water (and other fluid) flow in the nano-scale matrix in shale.

\subsection{Equilibrium-disequilibrium transitions in perturbed shale}


800 The combination of heterogeneous rock texture and composition, heterogeneous surface forces acting on the solid and fluid (liquid and gas) constituents, and the potential separation of fluid types (water and hydrocarbons) based on their interactions with wetting and non-wetting surfaces suggests an added heterogeneity in the fluid distribution and the fluid pressure. The available models for coupled poro-elastic behavior are described by poro-elastic coefficients developed based on an assumption of homogeneous rock properties, homogeneous stresses, and hydraulic pressure equilibration. These models cannot be extrapolated to mudrocks, particularly due to the coarse - $2 \mathrm{ft}(60 \mathrm{~cm})$ - volumetric averages typical for well-log measurements. The typical examples of perturbations include injection of $\mathrm{CO}_{2}$ (into sandstone storage formations with shale caprock) and unconventional gas extraction by hydraulic fracturing of shale. In both cases, the initial state of shale formation is either at steady-state, or at equilibrium, before the drilling and introduction of large volumes of fluid disrupt the initial state. The response of the geologic system to this perturbation is non-linear in space and time, since for re-equilibration it has to reach a multi-component - equilibrium, not an independent equilibrium of each of the components (e.g., hydraulic equilibrium). For example, the overall fluid flow and pressure equilibration for fine-grained rocks is controlled by chemical effects (osmosis), surface effects (capillary), physical effects (electrical double layer), and thermal gradient effects (relative expansion between solids and fluids in relation to hydraulic diffusion and thermal diffusion). The deformation versus pore pressure equilibration of organic-rich laminated mudrocks has the same contributions as considered for other fine-grained rocks, complicated by complex distribution of

821 homogenized Biot's coefficient; new models are required to define coupled behaviors in locally 822 heterogeneous media.

824 The state of geochemical (dis)equilibrium is usually assessed by analyzing fluid samples.

825 Detailed chemical and isotopic analyses of pore waters in shale and tight reservoirs have been 826 reported for only a few recent case studies ${ }^{[61,62,101,167]}$. Chemical and isotopic data reported by 827 oil companies from approximately 10,000 samples of 'flowback' and produced waters from 828 these unconventional sources of petroleum have been recently compiled and added to the updated and expanded USGS Produced Waters Geochemical Database ${ }^{[168]}$. The reported salinity 
and chemical composition of water varies widely with time of sampling and carry large uncertainties, especially for the 'flowback' samples that are a variable mixture of pore formation water and the hydraulic fracturing fluids, which consist of large volumes $\left(\sim 10,000-40,000 \mathrm{~m}^{3}\right.$ per well) of generally fresh, local meteoric water, together with proppants (sand), and organic and inorganic chemicals additives ${ }^{[169-172]}$. During hydraulic fracturing, a significant fraction of the injected water can be imbibed into pores in some shales (e.g. Marcellus ${ }^{[62,165]}$ ), and the imbibition process may continue over a period of weeks to months ${ }^{[157,158]}$. Water salinities and chemical compositions obtained at steady chemical states, which may require a year or longer following production, vary greatly from basin to basin. Results show formation waters with relatively low salinities are present in Fayetteville Shale, AR $\left(\sim 15,000 \mathrm{mg} \mathrm{L}^{-1}\right)$ and in Monterey Formation, CA $\left(\sim 30,000 \mathrm{mg} \mathrm{L}^{-1}\right)$. Produced water salinities in Barnett Shale, TX, average at $\sim 100,000 \mathrm{mg} \mathrm{L}^{-1}$, but higher average salinities $\left(\sim 150,000 \mathrm{mg} \mathrm{L}^{-1}\right)$ are obtained in brines from the Marcellus Shale, PA, and Haynesville, TX; even higher average salinities (>250,000 mg L-1) are observed in brine in Bakken Shale. An important initial conclusion from these data is that the chemical and isotopic compositions of these samples are comparable with data from more than 150,000 samples currently listed in the same USGS Produced Waters Geochemical Database, but collected from conventional oil and gas wells ${ }^{[168]}$. It remains challenging, however, to use this geochemical data for predictive modeling.

\section{Conclusions: Approaches for Coupled Process Studies and Future Research Needs}

\subsection{Summary of applied approaches/methodologies}

Table 2 indicates the various common data types relevant to shales, and their spatial and temporal resolution as well as well-established methods for integration of multi-disciplinary data.

Promising approaches for addressing coupled processes so far included dynamic consolidation problems with elastoplastic deformation and finite element modeling (FEM) ${ }^{[173-177]}$, quasi-static discrete element models (DEM) coupled with conjugate lattice network flow ${ }^{[178]}$, Basin Petroleum System Modeling ${ }^{[64]}$, incorporating Knudsen diffusion and gas slippage (in addition to Darcy flow) into reservoir models for shale ${ }^{[179]}$, and lattice Boltzmann (LB) approaches for 
coupled multi-component reactive flow and transport with the feedback between pore structure changes and flow processes ${ }^{[180,181]}$. The typical measurement resolution and modeling methods used for single and coupled processes in shale are shown in Figure 13.

The physics-based hydraulic fracturing simulator ${ }^{[178]}$ couples a quasi-static discrete element model for deformation and fracturing with conjugate lattice network flow model for fluid flow in both fractures and porous matrix. This two-dimensional model with coupled deformation and flow reproduces growth patterns of hydraulic fractures. The model accounts for in situ stress, fluid viscosity, heterogeneity of rock mechanical properties and injection rate. The modeling of a multistage horizontal wellbore confirms the strong coupling between observed complex fracture patterns and fluid pressure, small length scale heterogeneities, and elastic interactions among multiple propagating fractures ${ }^{[178]}$.

The lattice Boltzmann method is used for modeling pore-scale reactive transport and allows accounting for complex biogeochemical processes - mineral dissolution-precipitation and biofilm dynamics, and their feedback to transport (e.g. ${ }^{[182]}$ ). LB models conceptualize flow as a collective behavior of pseudo-particles described by a discrete Boltzmann equation ${ }^{[182]}$. In shale applications, LB modeling is capable of predicting permeability and effective Knudsen diffusivity of the shale samples characterized by FIB-SEM ${ }^{[180]}$. LB models have been applied to multi-phase flow with phase transition ${ }^{[183]}$ and development of preferential flow paths in porous media ${ }^{[184]}$.

Basin Petroleum System Modeling is relatively new for unconventional hydrocarbon resources and is still under development and refinement. Basin-scale shale-play modeling accounts for source-rock kinetics and chemical transformations, including the evolution of TOC and associated porosity and adsorption of hydrocarbons to the mineral and organic components ${ }^{\text {[64] }}$. However, this modeling approach does not account for the chemical effects due to nano-scale confinement, non-Darcy transport process (e.g., Knudsen transport), and complex cementation/dissolution textures. The retention capacity in BPSM is also a coupled process between burial, uplift and geomechanical rock properties since the in situ fluid pressures are ultimately determined by the fracture gradient that a shale can sustain as a result of overburden 
892 loss during uplift. One of the most important challenges for resource assessment in

893

894

895

896

897

898

899

900

901

902

903

904

905

906

907

908

909

910

911

912

913

914

915

916

917

918

919

920

921 unconventional plays is the need to quantitatively model the retention capacity of such organicrich source rocks.

\section{Figure 13.}

\subsection{Coupled processes in shale: future research needs}

The development of quantitative predictive models capturing process coupling and emergent phenomena at the necessary length and temporal scales requires a systematic approach involving a broad range of multi-disciplinary techniques. Current research is hindered due to sparse data from shale formations at in situ pressure and temperature conditions, limited spatial resolution of the well-logging/interpretation techniques, and methodologies for merging multi-disciplinary datasets at different length and time scales. Therefore, on the practical side, it is critical to define the type of relevant measurements, improve the resolution and link in situ well resistivity logging to chemistry, and develop better approaches for representative or standardized sampling and sample preservation. In particular, addressing heterogeneity and anisotropy, which leads to scaling complexity, is a major challenge. Below, we identify future research needs critical for fundamental and applied shale science, considering both single- and multi-disciplinary approaches.

It is necessary to develop unambiguous classification schemes for mudrocks, and develop further

14 understanding of the material transport and cementation mechanisms during shale deposition and diagenesis. We also need to establish the range of sizes for REVs, which are different for kerogen, clay mineral-rich components, and individual lithofacies, and are controlled by the unique depositional and diagenetic history. As shown in our review, the complex cementation and dissolution textures - both solid components and pores in shale - control the fluid transport, chemical behavior, and mechanical properties. Understanding fundamental geological/chemical/physical controls on the formation of these textures, and proposing a comprehensive classification scheme, could lay the foundation for the development of predictive 
922

methods to understand physical flow, chemical behavior and reactive transport, and mechanical behavior of shale in native state and in engineered systems.

Another key research area is developing robust methods for integrating rock anisotropy into geomechanical analysis, especially proper characterization and modeling of mechanical interfaces, and developing new constitutive laws describing stress-strain relationships for shale. Seismic methods show promise in characterizing fractures; however, research is needed to understand the contributions to the scattered wave field from fracture intersections, fracture sets, stress gradients and fluids in the dynamically evolving fractured shale systems. To further refine the interpretation of seismic data, and to characterize dynamically evolving fracture populations, seismic data needs to be integrated with high resolution imaging. A potential bridge here is the integration of high resolution image logs (centimeter scale) with petrological studies (micron scale) that may be upscaled to the seismic scale. The upscaling issue dominates the use of seismic methods for quantitative assessment of reservoir rock properties at all scales. Future research should focus on separating competing sources of anisotropy in rock and fluid flow, and how seismic signals change as a function of stress and fluid conditions. Future research needs to answer the fundamental question - can seismic data differentiate or unravel chemical, fluid and stress alteration of fractures?

The geochemistry of shale is unique, characterized by high salinity, complex compositions of brine and solids, water-limited, and nano-scale confined chemical environments, resulting in ionselectivity and semi-permeable membrane behavior. In order to interpret and predict the chemical behavior in these environments, we need to develop new thermodynamic databases, as well as a systematic approach for predicting shifts in chemical kinetics under these conditions. Fundamental science of nanogeochemistry is still in its infancy.

As shown in our review, process coupling exerts major controls on the physical, mechanical and chemical behavior of shale. Further development of coupled models is crucial for predicting coupled fracture, multi-phase flow, and multi-component reactive transport in the subsurface. New models are required to address coupled behavior in locally heterogeneous shale media. For the development of these models, the solid solvers need to be coupled in a 2-way manner to the 
multi-phase reactive flow and transport codes, and incorporate changes in volume and chemical concentrations, and their feedback to the mechanical properties and permeability. Due to complex pore geometries and the large variety of pore types and their control on the flow processes in shale, the development of a porosity-permeability relationship is a challenge. Since fluid flow in shale is coupled to the mechanical behavior, a method is required for computing the effect of flow on the mechanical constitutive behavior of shale (as partially-drained or undrained medium). These models should also incorporate multi-porosity system behavior, as distinct pore networks in organic and mineral components can exhibit different stiffness/compliance as a function of stress, resulting in different time scales of permeability evolution. Additional laboratory data for calibration and verification of these coupled models is necessary.

Further development of data integration approaches is another critical research need, due to the primary controls that the nano-scale processes exert on the macro-scale behavior. In an ideal case, we should be able to merge data all the way from the mineral-water interface (subnanometer), to rock microstructure observations (micron), to the core-scale samples (centimetermeter), well-log scale (meters), and linking to seismic scale (many meters to kilometers) (Table 2).

For developing fully coupled multi-physics multi-scale models for shale, we need a fundamental understanding of the interplay between the physical and chemical processes, their rates and resulting emergent behavior. We need to understand and quantify the evolution of thermal, hydrologic, chemical, mechanical, and biological (dis)equilibrium during perturbations (withdrawal or emplacement of materials into subsurface), and identify the relevant representative elementary volumes, as well as representative elementary time scales. Further development in constitutive laws (or, equations of state) is needed to incorporate evolving stresspressure and system transitions. This requires advanced modeling linking molecular-, to pore-, to macroscopic-scale processes and the formalization of heterogeneity and spatial and temporal scales. We need to improve and merge conceptual models and develop a common language for the multi-disciplinary research on coupled THCMB processes in shale.

\section{Acknowledgements}


This review article is an outgrowth of the "Shales at All Scales: Exploring Coupled Processes" workshop, held in Santa Fe, New Mexico, June 9-11, 2015. We thank the workshop attendeesscientists from academia, industry and national laboratories - who highlighted recent advances in shale science, and brainstormed research needs and approaches for the next level of advancement. The Workshop was sponsored by Sandia National Laboratories. Sandia National Laboratories is a multi-mission laboratory managed and operated by Sandia Corporation, a wholly owned subsidiary of Lockheed Martin Corporation, for the U.S. Department of Energy's National Nuclear Security Administration under contract DE-AC04-94AL85000. We thank Susan Altman for reviewing an early draft of the manuscript, and the anonymous reviewer for the constructive comments on the submitted version. For AGI, work relevant to the chemical controls on fracture is supported as part of the Center for Frontiers in Subsurface Energy Security (CFSES), an Energy Frontier Research Center funded by the U.S. Department of Energy (DOE), Office of Science, Basic Energy Sciences (BES), under Award \# DESC0001114. For DRC, TJK, and LJPN work was supported as part of the Center for Nanoscale Controls on Geologic $\mathrm{CO}_{2}$ (NCGC), an Energy Frontier Research Center funded by the U.S. Department of Energy, Office of Science, Basic Energy Sciences under Award \# DE-AC0205CH11231. For LJPN, work related to wave propagation in fractured anisotropic media was supported by the U.S. Department of Energy, Office of Science, Office of Basic Energy Sciences and the Geosciences Research Program under Award Number (DE-FG02-09ER16022).

\section{References}

[1] Folk R. Petrology of Sedimentary Rocks 1980 (Hemphill Publishing Company: Austin). [2] Milliken K. A compositional classification for grain assemblages in fine-grained sediments and sedimentary rocks. Journal of Sedimentary Research. 2014, 84(12), 1185-99. [3] Tucker ME. Sedimentary petrology: an introduction to the origin of sedimentary rocks 2009 (John Wiley \& Sons).

[4] Boggs S. Principles of sedimentology and stratigraphy 2006.

[5] Garrels RM, Mackenzie FT. Sedimentary rock types: relative proportions as a function of geological time. Science. 1969, 163(3867), 570-1.

[6] Blatt H. Sedimentary petrology. 1982.

[7] Jin L, Ogrinc N, Yesavage T, Hasenmueller EA, Ma L, Sullivan PL, et al. The CO 2 consumption potential during gray shale weathering: insights from the evolution of carbon isotopes in the Susquehanna Shale Hills critical zone observatory. Geochimica et Cosmochimica Acta. 2014, 142, 260-80. 
1019 [8] Galloway WE, Hobday DK, Magara K. Frio formation of the Texas Gulf Coast Basin-

1020 Depositional systems, structural framework, and hydrocarbon origin, migration, distribution, and 1021 exploration potential. Rep Invest, Univ Tex Austin, Bur Econ Geol;(United States). 1982, 122.

1022 [9] Milliken K. Late diagenesis and mass transfer in sandstone-shale sequences. Treatise on 1023

1024

1025

1026

1027

1028

1029

1030

1031

1032

1033

1034

1035

1036

1037

1038

1039

1040

1041

1042

1043

1044

1045

1046

1047

1048

1049

1050

1051

1052

1053

1054

1055

1056

1057

1058 Geochemistry: Sediments, Diagenesis and Sedimentary rocks, edited by Mackenzie, FT, Holland, HD, and Turekian, KK, Elsevier, New York. 2004, 7, 159-90.

[10] Ross DJ, Bustin RM. The importance of shale composition and pore structure upon gas storage potential of shale gas reservoirs. Marine and Petroleum Geology. 2009, 26(6), 916-27. [11] Loucks RG, Reed RM, Ruppel SC, Jarvie DM. Morphology, genesis, and distribution of nanometer-scale pores in siliceous mudstones of the Mississippian Barnett Shale. Journal of sedimentary research. 2009, 79(12), 848-61.

[12] Chalmers GR, Bustin RM, Power IM. Characterization of gas shale pore systems by porosimetry, pycnometry, surface area, and field emission scanning electron microscopy/transmission electron microscopy image analyses: Examples from the Barnett, Woodford, Haynesville, Marcellus, and Doig units. AAPG Bulletin. 2012, 96(6), 1099-119. [13] Nelson PH. Pore-throat sizes in sandstones, tight sandstones, and shales. AAPG bulletin. 2009, 93(3), 329-40.

[14] Potter PE, Maynard JB, Depetris PJ. Mud and mudstones: Introduction and overview 2005 (Springer Science \& Business Media).

[15] Cook A, Sherwood N. Classification of oil shales, coals and other organic-rich rocks. Organic Geochemistry. 1991, 17(2), 211-22.

[16] Dean WE, Leinen M, Stow DA. Classification of deep-sea, fine-grained sediments. Journal of Sedimentary Research. 1985, 55(2).

[17] Aplin AC, Macquaker JH. Mudstone diversity: Origin and implications for source, seal, and reservoir properties in petroleum systems. AAPG bulletin. 2011, 95(12), 2031-59.

[18] Lazar OR, Bohacs KM, Macquaker JH, Schieber J, Demko TM. Capturing key attributes of fine-grained sedimentary rocks in outcrops, cores, and thin sections: nomenclature and description guidelines. Journal of Sedimentary Research. 2015, 85(3), 230-46.

[19] Bourg IC. Sealing Shales versus Brittle Shales: A Sharp Threshold in the Material Properties and Energy Technology Uses of Fine-Grained Sedimentary Rocks. Environmental Science \& Technology Letters. 2015, 2(10), 255-9.

[20] Wawak BE, Diaz E, Camp WK. Electron microscopy of shale hydrocarbon reservoirs 2013.

[21] Schieber J, Southard J, Thaisen K. Accretion of mudstone beds from migrating floccule ripples. Science. 2007, 318(5857), 1760-3.

[22] Vernon RH. A practical guide to rock microstructure 2004 (Cambridge university press).

[23] Akkutlu IY, Fathi E. Multiscale gas transport in shales with local kerogen

heterogeneities. SPE-167234-PA. 2012, 17(04), 1,002-1,11.

[24] Saraji S, Piri M. The representative sample size in shale oil rocks and nano-scale characterization of transport properties. International Journal of Coal Geology. 2015, 146, 42-54.

1059

1060

1061

1062 [25] Mondol NH, Bjørlykke K, Jahren J, Høeg K. Experimental mechanical compaction of clay mineral aggregates - Changes in physical properties of mudstones during burial. Marine and Petroleum Geology. 2007, 24(5), 289-311.

1063 Turekian K)2014, (Elsevier Sciecne: Amsterdam). 
1064

1065

1066

1067

1068

1069

1070

1071

1072

1073

1074

1075

1076

1077

1078

1079

1080

1081

1082

1083

1084

1085

1086

1087

1088

1089

1090

1091

1092

1093

1094

1095

1096

1097

1098

1099

1100

1101

1102

1103

1104

1105

1106

1107

1108

[27] Hitchon B, Billings GK, Klovan J. Geochemistry and origin of formation waters in the western Canada sedimentary basin-III. Factors controlling chemical composition. Geochimica et Cosmochimica Acta. 1971, 35(6), 567-98.

[28] Hanor JS. Origin of saline fluids in sedimentary basins. Geological Society, London, Special Publications. 1994, 78(1), 151-74.

[29] Kharaka Y, Maest A, Carothers W, Law L, Lamothe P, Fries T. Geochemistry of metalrich brines from central Mississippi Salt Dome basin, USA. Applied Geochemistry. 1987, 2(5), 543-61.

[30] Capo RC, Stewart BW, Rowan EL, Kohl CAK, Wall AJ, Chapman EC, et al. The strontium isotopic evolution of Marcellus Formation produced waters, southwestern Pennsylvania. International Journal of Coal Geology. 2014, 126, 57-63.

[31] Macquaker JH, Keller MA, Davies SJ. Algal blooms and "marine snow": Mechanisms that enhance preservation of organic carbon in ancient fine-grained sediments. Journal of Sedimentary Research. 2010, 80(11), 934-42.

[32] Schieber J. Microbial mats in the siliciclastic rock record: a summary of diagnostic features. The precambrian earth: tempos and events Developments in Precambrian geology.

2004, 12, 663-73.

[33] Hower J, Mowatt TC. The mineralogy of illites and mixed-layer illite/montmorillonites. American Mineralogist. 1900, 51(5-6).

[34] Towe KM. Clay mineral diagenesis as a possible source of silica cement in sedimentary rocks. Journal of Sedimentary Research. 1962, 32(1).

[35] Lynch FL, Mack LE, Land LS. Burial diagenesis of illite/smectite in shales and the origins of authigenic quartz and secondary porosity in sandstones. Geochimica et Cosmochimica Acta. 1997, 61(10), 1995-2006.

[36] Thyberg B, Jahren J, Winje T, Bjørlykke K, Faleide JI, Marcussen Ø. Quartz cementation in Late Cretaceous mudstones, northern North Sea: changes in rock properties due to dissolution of smectite and precipitation of micro-quartz crystals. Marine and Petroleum Geology. 2010, 27(8), 1752-64.

[37] Osborne MJ, Swarbrick RE. Mechanisms for generating overpressure in sedimentary basins: a reevaluation. AAPG bulletin. 1997, 81(6), 1023-41.

[38] Rask J, Bryndzia L, Braunsdorf N, Murray T. Smectite illitization in Pliocene-age Gulf of Mexico mudrocks. Clays and Clay Minerals. 1997, 45(1), 99-109.

[39] Osborne MJ, Swarbrick RE. Diagenesis in North Sea HPHT clastic reservoirs-

Consequences for porosity and overpressure prediction. Marine and Petroleum Geology. 1999, 16(4), 337-53.

[40] Swarbrick RE, Osborne MJ, Yardley GS. AAPG Memoir 76, Chapter 1: Comparision of Overpressure Magnitude Resulting from the Main Generating Mechanisms. 2001.

[41] Gale JF, Laubach SE, Olson JE, Eichhubl P, Fall A. Natural fractures in shale: A review and new observations. AAPG bulletin. 2014, 98(11), 2165-216.

[42] Dusseault MB. Coupled processes and petroleum geomechanics. Elsevier GeoEngineering Book Series. 2004, 2, 49-62.

[43] Javadpour F. Nanopores and apparent permeability of gas flow in mudrocks (shales and siltstone). Journal of Canadian Petroleum Technology. 2009, 48(08), 16-21.

[44] Milliken KL, Curtis ME. Imaging Pores in Sedimentary Rocks: Foundation of Porosity Prediction. Marine and Petroleum Geology. 2016. 
[45] Milliken KL, Day-Stirrat RJ. Cementation in mudrocks: brief review with examples from cratonic basin mudrocks. 2013.

[46] Dove PM. Geochemical controls on the kinetics of quartz fracture at subcritical tensile stresses. Journal of Geophysical Research: Solid Earth. 1995, 100(B11), 22349-59.

[47] Petsch S, Edwards K, Eglinton T. Microbial transformations of organic matter in black shales and implications for global biogeochemical cycles. Palaeogeography, Palaeoclimatology, Palaeoecology. 2005, 219(1), 157-70.

[48] Fredrickson J, McKinley J, Bjornstad B, Long P, Ringelberg D, White D, et al. Pore-size constraints on the activity and survival of subsurface bacteria in a late cretaceous shale-sandstone sequence, northwestern New Mexico. Geomicrobiology Journal. 1997, 14(3), 183-202.

[49] Struchtemeyer CG, Davis JP, Elshahed MS. Influence of the drilling mud formulation process on the bacterial communities in thermogenic natural gas wells of the Barnett Shale. Applied and environmental microbiology. 2011, 77(14), 4744-53.

[50] Ilgen AG, Cygan RT. Mineral dissolution and precipitation during CO 2 injection at the Frio-I Brine Pilot: Geochemical modeling and uncertainty analysis. International Journal of Greenhouse Gas Control. 2016, 44, 166-74.

[51] Kharaka Y, Cole DR, Hovorka SD, Gunter W, Knauss K, Freifeld BM. Gas-water-rock interactions in Frio Formation following $\mathrm{CO}_{2}$ injection: Implications for the storage of greenhouse gases in sedimentary basins. Geology. 2006, 34(7), 577-80.

[52] Olivella S, Alonso E. Modelling gas flow through deformable fractured rocks. Coupled Thermo-hydro-mechanical-chemical Processes in Geo-systems: Fundamentals, Modelling, Experiments and Applications. 2004, 2, 31.

[53] Choi S, Ta C, Freij-Ayou R. A Coupled mechanical-thermal-physico-chemical model for the study of time-dependent wellbore stability in shales. Elsevier Geo-Engineering Book Series. 2004, 2, 581-6.

[54] Schneider J, Flemings PB, Day-Stirrat RJ, Germaine JT. Insights into pore-scale controls on mudstone permeability through resedimentation experiments. Geology. 2011, 39(11), 1011-4. [55] Evans J. Quartz dissolution during shale diagenesis implications for quartz cementation in sandstones. Chemical Geology. 1990, 84(1), 239-40.

[56] Milliken KL. Cathodoluminescent Textures and the Origin of Quarts Silt in Oligocene Mudrocks, South Texas. Journal of Sedimentary Research. 1994, 64(3).

[57] Boles JR, Franks SG. Clay diagenesis in Wilcox sandstones of southwest Texas: implications of smectite diagenesis on sandstone cementation. Journal of Sedimentary Research. 1979, 49(1).

[58] Bjørlykke K, Aagaard P, Egeberg PK, Simmons SP. Geochemical constraints from formation water analyses from the North Sea and the Gulf Coast Basins on quartz, feldspar and illite precipitation in reservoir rocks. Geological Society, London, Special Publications. 1995, 86(1), 33-50.

[59] Franks SG, Zwingmann H. Origin and timing of late diagenetic illite in the PermianCarboniferous Unayzah sandstone reservoirs of Saudi Arabia. AAPG bulletin. 2010, 94(8), 1133-59.

[60] Kharaka YK, Gans K, Rowan E, Thordsen J, Conaway C, Blondes M, et al. in Subsurface Science and Engineering of Shale Eds. Dewers TA, Sanchez M, Heath JE)2016, (American Geophysical Union/Wiley).

[61] Haluszczak LO, Rose AW, Kump LR. Geochemical evaluation of flowback brine from Marcellus gas wells in Pennsylvania, USA. Applied Geochemistry. 2013, 28, 55-61. 
[62] Rowan EL, Engle MA, Kraemer TF, Schroeder KT, Hammack RW, Doughten MW. Geochemical and isotopic evolution of water produced from Middle Devonian Marcellus shale gas wells, Appalachian basin, Pennsylvania. AAPG Bulletin. 2015, 99(2), 181-206.

[63] Al-Hajeri MM, Al Saeed M, Derks J, Fuchs T, Hantschel T, Kauerauf A, et al. Basin and petroleum system modeling. Oilfield Review. 2009, 21(2), 14-29.

[64] Romero-Sarmiento M-F, Ducros M, Carpentier B, Lorant F, Cacas M-C, Pegaz-Fiornet $\mathrm{S}$, et al. Quantitative evaluation of TOC, organic porosity and gas retention distribution in a gas shale play using petroleum system modeling: application to the Mississippian Barnett Shale. Marine and Petroleum Geology. 2013, 45, 315-30.

[65] Suarez-Rivera R. in SPE ATW Shale as Reservoir: development Challenges and Solutions 2011, (Barcelona, Spain).

[66] Goodman RE, Shi G-h. Block theory and its application to rock engineering 1985 (Prentice-Hall Englewood Cliffs, NJ).

[67] Suarez-Rivera R, Behrmann LA, Green S, Burghardt J, Stanchits S, Edelman E, et al. in SPE Annual Technical Conference and Exhibition 2013, (Society of Petroleum Engineers).

[68] Shao S. 2015, Purdue University.

[69] Shao S, Pyrak-Nolte LJ. Interface waves along fractures in anisotropic media. Geophysics. 2013, 78(4), T99-T112.

[70] Shao S, Petrovitch C, Pyrak-Nolte L. Wave guiding in fractured layered media. Geological Society, London, Special Publications. 2015, 406(1), 375-400.

[71] Choi M-K, Bobet A, Pyrak-Nolte LJ. The effect of surface roughness and mixed-mode loading on the stiffness ratio $\kappa \mathrm{x} / \kappa \mathrm{z}$ for fractures. Geophysics. 2014, 79(5), D319-D31.

[72] Far ME, de Figueiredo JJ, Stewart RR, Castagna JP, Han D-H, Dyaur N. Measurements of seismic anisotropy and fracture compliances in synthetic fractured media. Geophysical Journal International. 2014, ggu101.

[73] Hobday C, Worthington M. Field measurements of normal and shear fracture compliance. Geophysical Prospecting. 2012, 60(3), 488-99.

[74] Verdon JP, Wüstefeld A. Measurement of the normal/tangential fracture compliance ratio (ZN/ZT) during hydraulic fracture stimulation using S-wave splitting data. Geophysical Prospecting. 2013, 61(s1), 461-75.

[75] Lubbe R, Worthington M. A field investigation of fracture compliance. Geophysical Prospecting. 2006, 54(3), 319-31.

[76] Lubbe R, Sothcott J, Worthington M, McCann C. Laboratory estimates of normal and shear fracture compliance. Geophysical Prospecting. 2008, 56(2), 239-47.

[77] Majer E, McEvilly TV, Eastwood F, Myer L. Fracture detection using P-wave and Swave vertical seismic profiling at The Geysers. Geophysics. 1988, 53(1), 76-84.

[78] Pyrak-Nolte LJ, Myer LR, Cook NG. Transmission of seismic waves across single natural fractures. Journal of Geophysical Research: Solid Earth. 1990, 95(B6), 8617-38. [79] Pyrak-Nolte LJ, Myer LR, Cook NG. Anisotropy in seismic velocities and amplitudes from multiple parallel fractures. Journal of Geophysical Research: Solid Earth. 1990, 95(B7), 11345-58.

[80] Sayers CM, Taleghani AD, Adachi J. The effect of mineralization on the ratio of normal to tangential compliance of fractures. Geophysical Prospecting. 2009, 57(3), 439-46.

[81] Pyrak-Nolte L, Morris J. Single fractures under normal stress: The relation between fracture specific stiffness and fluid flow. International Journal of Rock Mechanics and Mining Sciences. 2000, 37(1), 245-62. 
[82] Cook N. in International Journal of Rock Mechanics and Mining Sciences \& Geomechanics Abstracts 1992, pp. 198-223 (Elsevier).

[83] Petrovitch CL, Nolte DD, Pyrak-Nolte LJ. Scaling of fluid flow versus fracture stiffness. Geophysical Research Letters. 2013, 40(10), 2076-80.

[84] Petrovitch CL. Scaling of the flow-stiffness relationship in weakly correlated single fractures. 2013.

[85] Pyrak-Nolte LJ, Nolte DD. Approaching a universal scaling relationship between fracture stiffness and fluid flow. Nature communications. 2016, 7.

[86] Anderson OL, Grew PC. Stress corrosion theory of crack propagation with applications to geophysics. Reviews of Geophysics. 1977, 15(1), 77-104.

[87] Swanson PL. Subcritical crack growth and other time-and environment-dependent behavior in crustal rocks. Journal of Geophysical Research: Solid Earth. 1984, 89(B6), 4137-52. [88] Holder J, Olson JE, Philip Z. Experimental determination of subcritical crack growth parameters in sedimentary rock. Geophysical Research Letters. 2001, 28(4), 599-602.

[89] Hu M, Hueckel T. Environmentally enhanced crack propagation in a chemically degrading isotropic shale. Geotechnique. 2013, 63(4), 313.

[90] Schultz R. Growth of geologic fractures into large-strain populations: review of nomenclature, subcritical crack growth, and some implications for rock engineering. International Journal of Rock Mechanics and Mining Sciences. 2000, 37(1), 403-11. [91] Gale JF, Laubach SE, Marrett RA, Olson JE, Holder J, Reed RM. Predicting and characterizing fractures in dolostone reservoirs: Using the link between diagenesis and fracturing. Geological Society, London, Special Publications. 2004, 235(1), 177-92. [92] Carey JW, Lei Z, Rougier E, Mori H, Viswanathan H. Fracture-permeability behavior of shale. Journal of Unconventional Oil and Gas Resources. 2015, 11, 27-43.

[93] Lei Z, Rougier E, Knight E, Munjiza A. A framework for grand scale parallelization of the combined finite discrete element method in 2d. Computational Particle Mechanics. 2014, 1(3), 307-19.

[94] Akkutlu IY, Efendiev Y, Savatorova V. Multi-scale asymptotic analysis of gas transport in shale matrix. Transport in Porous Media. 2015, 107(1), 235-60.

[95] Heath JE, Dewers TA, McPherson BJ, Petrusak R, Chidsey TC, Rinehart AJ, et al. Pore networks in continental and marine mudstones: Characteristics and controls on sealing behavior. Geosphere. 2011, 7(2), 429-54.

[96] Gensterblum Y, Ghanizadeh A, Cuss RJ, Amann-Hildenbrand A, Krooss BM, Clarkson $\mathrm{CR}$, et al. Gas transport and storage capacity in shale gas reservoirs-A review. Part A: Transport processes. Journal of Unconventional Oil and Gas Resources. 2015, 12, 87-122.

[97] Sakhaee-Pour A, Bryant S. Gas Permeability of Shale. SPE-146944-PA. 2012, August 2012

[98] Mehmani A, Prodanović M, Javadpour F. Multiscale, multiphysics network modeling of shale matrix gas flows. Transport in porous media. 2013, 99(2), 377-90.

[99] Eliyahu M, Emmanuel S, Day-Stirrat RJ, Macaulay CI. Mechanical properties of organic matter in shales mapped at the nanometer scale. Marine and Petroleum Geology. 2015, 59, 294304.

[100] Freeman C, Moridis G, Blasingame T. A numerical study of microscale flow behavior in tight gas and shale gas reservoir systems. Transport in porous media. 2011, 90(1), 253-68.

[101] Arthur MA, Cole DR. Unconventional hydrocarbon resources: prospects and problems. Elements. 2014, 10(4), 257-64. 
[102] Trebotich D, Graves D. An adaptive finite volume method for the incompressible Navier-Stokes equations in complex geometries. Communications in Applied Mathematics and 1249 Computational Science. 2015, 10(1), 43-82. [103] Yoon H, Dewers TA. Nanopore structures, statistically representative elementary volumes, and transport properties of chalk. Geophysical Research Letters. 2013, 40(16), 4294-8. [104] Chen C, Hu D, Westacott D, Loveless D. Nanometer-scale characterization of microscopic pores in shale kerogen by image analysis and pore-scale modeling. Geochemistry, Geophysics, Geosystems. 2013, 14(10), 4066-75.

[105] Gelb J, Gu A, Fong T, Hunter L, Lau S, Yun W. in Proc SCA 2011.

[106] Rui K, Akkutlu I. Molecular Dynamics Simulation Approach in Estimating Organic-rich Shale Permeability. SPE-180112 presented at the SPE EUROPEC featured at 78th EAGE Conference and Exhibition, Vienna, Austria 30 May-2 June.

[107] Purcell W. Capillary pressures-their measurement using mercury and the calculation of permeability therefrom. Journal of Petroleum Technology. 1949, 1(02), 39-48.

[108] Washburn EW. The dynamics of capillary flow. Physical review. 1921, 17(3), 273.

[109] Ho TA, Striolo A. Water and methane in shale rocks: Flow pattern effects on fluid transport and pore structure. AIChE Journal. 2015, 61(9), 2993-9.

[110] Wasaki A, Akkutlu IY. Permeability of Organic-rich Shale. SPE Journal, 2015, 20(6), 1384-96.

[111] Clarkson CR. Production data analysis of unconventional gas wells: Review of theory and best practices. International Journal of Coal Geology. 2013, 109, 101-46.

[112] Ezulike OD, Dehghanpour H. Capturing the effects of secondary fractures on production data using flow regime equations and specialised plots: An uncertainty analysis approach. Journal of Petroleum Science and Engineering. 2016, 138, 201-17. [113] Kuhlman KL, Malama B, Heath JE. Multiporosity flow in fractured low-permeability rocks. Water Resources Research. 2015, 51(2), 848-60.

[114] Bethke C. Geochemical and biogeochemical reaction modeling 2008 (Cambridge University Press Cambridge, UK).

[115] Suarez-Rivera R, Fjær E. Evaluating the poroelastic effect on anisotropic, organic-rich, mudstone systems. Rock mechanics and rock engineering. 2013, 46(3), 569-80.

[116] Ambrose RJ, Hartman RC, Diaz Campos M, Akkutlu IY, Sondergeld C. Shale Gas inplace Calculations Part I - New Pore-scale Considerations. SPE Journal. 2010, 17(1), 219-29. [117] Wang FP, Reed RM. in 2009 SPE Annual Technical Conference and Exhibition 2009, (Society of Petroleum Engineers: New Orleans, Louisiana, USA).

[118] Bennion DB, Thomas FB, Schulmeister BE, Rushing J. in Petroleum Society's Canadian International Petroleum Conference 2002, (Petroleum Society of Canada: Calgary, Alberta, Canada).

[119] Al-Bazali TM, Zhang J, Chenevert ME, Sharma MM. in 2009 SPE Offshore Europe Oil \& Gas Conference \& Exhibition 2009, (Society of Petroleum Engineers: Aberdeen, UK).

[120] Wang Y. Nanogeochemistry: nanostructures, emergent properties and their control on geochemical reactions and mass transfers. Chemical Geology. 2014, 378, 1-23.

[121] Firincioglu T, Ozkan E, Ozgen C. 2012, (Society of Petroleum Engineers).

[122] Wu Y-S. Multiphase Fluid Flow in Porous and Fractured Reservoirs 2015 (Gulf Professional Publishing).

[123] Teklu TW, Alharthy N, Kazemi H, Yin X, Graves RM, AlSumaiti AM. Phase Behavior and Minimum Miscibility Pressure in Nanopores. 2014. 
[124] Akkutlu IY, Rahmani DB. in SPE International Symposium on Oilfield Chemistry 2013, (Society of Petroleum Engineers).

[125] Ho TA, Criscenti LJ, Wang Y. Nanostructural control of methane release in kerogen and its implications to wellbore production decline. under review. 2016.

[126] Phan A, Cole DR, Striolo A. Aqueous methane in slit-shaped silica nanopores: high solubility and traces of hydrates. The Journal of Physical Chemistry C. 2014, 118(9), 4860-8. [127] Phan A, Cole DR, Striolo A. Factors governing the behaviour of aqueous methane in narrow pores. Phil Trans R Soc A. 2016, 374(2060), 20150019.

[128] Singh SK, Sinha A, Deo G, Singh JK. Vapor- liquid phase coexistence, critical properties, and surface tension of confined alkanes. The Journal of Physical Chemistry C. 2009, 113(17), 7170-80.

[129] Firincioglu T, Ozkan E, Ozgen C. in SPE Annual Technical Conference and Exhibition 2012, (Society of Petroleum Engineers).

[130] Rahmani Didar B, Akkutlu IY. 2013. Pore-size Dependence of Fluid Phase Behavior and Properties in Organic-rich Shale Reservoirs. SPE-164099, paper presented at the SPE Int. Symposium on Oilfield Chemistry in Woodlands, Texas, USA, 8-10 April.

[131] Cristancho D, Akkutlu IY, Criscenti L, Wang Y. 2016 Influence of Kerogen Pore Surface Heterogeneities on Methane Storage. SPE-180112 presented at the SPE EUROPEC featured at 78th EAGE Conference and Exhibition, Vienna, Austria 30 May-2 June.

[132] Marti J, Nagy G, Guardia E, Gordillo M. Molecular dynamics simulation of liquid water confined inside graphite channels: dielectric and dynamical properties. The Journal of Physical Chemistry B. 2006, 110(47), 23987-94.

[133] Senapati S, Chandra A. Dielectric constant of water confined in a nanocavity. The Journal of Physical Chemistry B. 2001, 105(22), 5106-9.

[134] Bourg IC, Steefel CI. Molecular dynamics simulations of water structure and diffusion in silica nanopores. The Journal of Physical Chemistry C. 2012, 116(21), 11556-64.

[135] Takei T, Mukasa K, Kofuji M, Fuji M, Watanabe T, Chikazawa M, et al. Changes in density and surface tension of water in silica pores. Colloid and Polymer Science. 2000, 278(5), 475-80.

[136] Kalluri RK, Konatham D, Striolo A. Aqueous NaCl solutions within charged carbon-slit pores: Partition coefficients and density distributions from molecular dynamics simulations. The Journal of Physical Chemistry C. 2011, 115(28), 13786-95.

[137] Wang Y, Bryan C, Xu H, Gao H. Nanogeochemistry: Geochemical reactions and mass transfers in nanopores. Geology. 2003, 31(5), 387-90.

[138] Diaz-Campos M, Akkutlu IY, Sigal RF. 2009. A Molecular Dynamics Study on Natural Gas Solubility Enhancement in Water Confined to Small Pores. SPE-124491, paper presented during SPE Annual Technical Conference and Exhibition in New Orleans, October 4-7. [139] Nelson J, Bargar J, Brown G, Maher K. in Goldschmidt Abstracts 2014.

[140] Zimmerman AR, Chorover J, Goyne KW, Brantley SL. Protection of mesopore-adsorbed organic matter from enzymatic degradation. Environmental Science \& Technology. 2004, 38(17), 4542-8. [141] Jung HB, Boyanov MI, Konishi H, Sun Y, Mishra B, Kemner KM, et al. Redox behavior of uranium at the nanoporous aluminum oxide-water interface: Implications for uranium remediation. Environmental science \& technology. 2012, 46(13), 7301-9. [142] Patra S, Pandey AK, Sarkar SK, Goswami A. Wonderful nanoconfinement effect on redox reaction equilibrium. RSC Advances. 2014, 4(63), 33366-9. 

Decomposition of Silver Citrate Complex in Nanoscale Confinement: An Unusual Mechanism of Formation and Growth of Silver Nanoparticles. Langmuir. 2014, 30(9), 2460-9. [144] Odusina EO, Sondergeld CH, Rai CS. in Canadian Unconventional Resources Conference 2011, (Society of Petroleum Engineers). [145] Hu Y, Devegowda D, Striolo A, Phan A, Ho TA, Civan F, et al. Microscopic Dynamics of Water and Hydrocarbon in Shale-Kerogen Pores of Potentially Mixed Wettability. SPE167234-PA. 2014, 112-24. [146] Nitao JJ, Bear J. Potentials and their role in transport in porous media. Water Resources Research. 1996, 32(2), 225-50.

[147] Eveline V, Akkutlu IY, Moridis G. 2016. Impact of Hydraulic Fracturing Fluid Damage on Shale Gas Well Production Performance. SPE-181677, paper presented during the SPE Annual Technical Conference and Exhibition in Dubai, UAE, September 26-28. in [148] Hillel D. Introduction to Soil Physics 1982 (Academic Press).

[149] Bustin RM, Bustin AMM, Cui A, Ross D, Pathi VM. in 2008 SPE Shale Gas Production Conference 2008, (Society of Petroleum Engineers: Fort Worth, Texas, U.S.A.).

Woodlands, Texas, USA).

[151] Desbois G, Urai JL, Kukla PA. Morphology of the pore space in claystones - evidence

1360

1361

1362

1363

1364

1365

1366

1367

1368

1369

1370

1371

1372

1373

1374

1375

1376

1377

1378

1379

1380

1381 from BIB/FIB ion beam sectioning and cryo-SEM observations. eEarth. 2009, 4(1), 15-22.

[152] Dewers TA, Heath J, Ewy R, Duranti L. Three-dimensional pore networks and transport properties of a shale gas formation determined from focused ion beam serial imaging. Int $\mathrm{J}$ of Oil, Gas and Coal Technology. 2012, 5(2/3), 229 - 48.

[153] Heath JE, Dewers TA, McPherson BJOL, Nemer MB, Kotula PG. Pore-lining phases and capillary breakthrough pressure of mudstone caprocks: Sealing efficiency of geologic CO2 storage sites. International Journal of Greenhouse Gas Control. 2012, 11, 204-20.

[154] Silin D, Kneafsey TJ. in Canadian Unconventional Resources Conference 2011, (Society of Petroleum Engineers).

[155] Or D, Tuller M. Liquid retention and interfacial area in variably saturated porous media: Upscaling from single-pore to sample-scale model. Water Resources Research. 1999, 35(12), 3591-605.

[156] Heath JE, Bryan CR, Matteo EN, Dewers TA, Wang Y, Sallaberry CJ. Adsorption and capillary condensation in porous media as a function of the chemical potential of water in carbon dioxide. Water Resources Research. 2014, 50(3), 2718-31.

[157] Byrnes AP. Role of induced and natural imbibition in frac fluid transport and fate in gas shales. for the Hydraulic Fracturing Study: Fate and Transport. 2011, 70.

[158] Nicot J-P, Scanlon BR, Reedy RC, Costley RA. Source and fate of hydraulic fracturing water in the Barnett Shale: a historical perspective. Environmental science \& technology. 2014, 48(4), 2464-71.

[159] Lomba RF, Chenevert M, Sharma MM. The role of osmotic effects in fluid flow through shales. Journal of Petroleum Science and Engineering. 2000, 25(1), 25-35.

[160] Lomba RF, Chenevert M, Sharma MM. The ion-selective membrane behavior of native shales. Journal of Petroleum Science and Engineering. 2000, 25(1), 9-23. 
[161] Chen G, Chenevert ME, Sharma MM, Yu M. A study of wellbore stability in shales including poroelastic, chemical, and thermal effects. Journal of Petroleum Science and Engineering. 2003, 38(3-4), 167-76. [162] Schlemmer R, Friedheim JE, Growcock FB, Bloys JB, Headley JA, Polnaszek SC. Chemical Osmosis, Shale, and Drilling Fluids. 2003.

[163] van Oort E, Hale AH, Mody FK. 1995, (Society of Petroleum Engineers).

[164] Engelder T. Capillary tension and imbibition sequester frack fluid in Marcellus gas shale. Proceedings of the National Academy of Sciences. 2012, 109(52), E3625-E.

[165] Engelder T, Cathles LM, Bryndzia LT. The fate of residual treatment water in gas shale. Journal of Unconventional Oil and Gas Resources. 2014, 7, 33-48.

[166] Ghanbari E, Dehghanpour H. Impact of rock fabric on water imbibition and salt diffusion in gas shales. International Journal of Coal Geology. 2015, 138, 55-67.

[167] Council GWP. Modern shale gas development in the United States: A primer 2009 (US Department of Energy, Office of Fossil Energy).

[168] Blondes M, Gans K, Thordsen J, Reidy M, Engle M, Kharaka Y, et al. (Ed. USGS)2015. [169] Kharaka Y, Thordsen JJ, Conaway CH, Thomas RB. The energy-water nexus: potential groundwater-quality degradation associated with production of shale gas. Procedia Earth and Planetary Science. 2013, 7, 417-22.

[170] Bryndzia LT, Braunsdorf NR. From source rock to reservoir: the evolution of selfsourced unconventional resource plays. Elements. 2014, 10(4), 271-6.

[171] Gallegos TJ, Varela BA, Haines SS, Engle MA. Hydraulic fracturing water use variability in the United States and potential environmental implications. Water Resources Research. 2015, 51(7), 5839-45.

[172] Healy RW, Alley WM, Engle MA, McMahon PB, Bales JD. 2015, (US Geological Survey).

[173] Lewis RW, Schrefler BA. The finite element method in the deformation and consolidation of porous media. 1987.

[174] De Borst R, Sluys L, Muhlhaus H-B, Pamin J. Fundamental issues in finite element analyses of localization of deformation. Engineering computations. 1993, 10(2), 99-121.

[175] Armero F. Formulation and finite element implementation of a multiplicative model of coupled poro-plasticity at finite strains under fully saturated conditions. Computer Methods in Applied Mechanics and Engineering. 1999, 171(3), 205-41.

[176] Kim JM. A fully coupled finite element analysis of water-table fluctuation and land deformation in partially saturated soils due to surface loading. International Journal for Numerical Methods in Engineering. 2000, 49(9), 1101-19.

[177] Chen L, Fang W, Kang Q, Hyman JDH, Viswanathan HS, Tao W-Q. Generalized lattice Boltzmann model for flow through tight porous media with Klinkenberg's effect. Physical Review E. 2015, 91(3), 033004.

[178] Huang H, Mattson E. in 48th US Rock Mechanics/Geomechanics Symposium 2014, (American Rock Mechanics Association).

[179] Swami V, Settari A. in SPE Americas Unconventional Resources Conference 2012, (Society of Petroleum Engineers).

[180] Chen L, Zhang L, Kang Q, Viswanathan HS, Yao J, Tao W. Nanoscale simulation of shale transport properties using the lattice Boltzmann method: permeability and diffusivity. Scientific reports. 2015, 5 . 
1428 [181] Chen L, Kang Q, Pawar R, He Y-L, Tao W-Q. Pore-scale prediction of transport 1429 properties in reconstructed nanostructures of organic matter in shales. Fuel. 2015, 158, 650-8.

1430 [182] Yoon H, Kang Q, Valocchi A. Lattice Boltzmann-based approaches for pore-scale 1431 reactive transport. Rev Mineral Geochem. 2015, 80, 393-431.

1432 [183] Shan X, Chen H. Lattice Boltzmann model for simulating flows with multiple phases and 1433 components. Physical Review E. 1993, 47(3), 1815.

1434 [184] Szymczak P, Ladd A. A network model of channel competition in fracture dissolution. 1435 Geophysical research letters. 2006, 33(5).

1436 [185] Campbell CV. Lamina, laminaset, bed and bedset. Sedimentology. 1967, 8(1), 7-26. 
Table 1. Two-way coupling of thermal, hydraulic, mechanical, chemical, and biological processes relevant to natural and engineered shale.

\begin{tabular}{|c|c|c|c|c|}
\hline 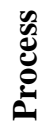 & Thermal & & & \\
\hline 蒻 & $\begin{array}{l}\text { Changes in fluid } \\
\text { buoyancy and viscosity, } \\
\text { change in fluid phase - } \\
\text { evaporation and } \\
\text { condensation. Thermal } \\
\text { diffusion and fluid } \\
\text { flow. Heat convection } \\
\text { by moving fluid. }\end{array}$ & Hydraulic & & \\
\hline 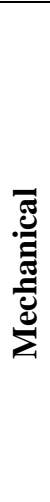 & $\begin{array}{l}\text { Conversion of } \\
\text { mechanical energy into } \\
\text { heat; thermal stress and } \\
\text { thermal expansion, } \\
\text { damage and } \\
\text { deformation. }\end{array}$ & $\begin{array}{l}\text { Stress-deformation- } \\
\text { damage controls on } \\
\text { porosity and permeability, } \\
\text { and fracture network } \\
\text { dynamics; aperture- } \\
\text { pressure-stiffness of } \\
\text { fracture as a function of } \\
\text { matrix effective stress; } \\
\text { capillary and swelling } \\
\text { pressure-relative } \\
\text { saturation. }\end{array}$ & Mechanical & \\
\hline שֶّ & $\begin{array}{l}\text { Temperature control on } \\
\text { chemical reaction rates } \\
\text { and mineral stability } \\
\text { fields; heat release from } \\
\text { exothermal chemical } \\
\text { reactions, involving } \\
\text { inorganic and organic } \\
\text { components. }\end{array}$ & $\begin{array}{l}\text { Fluid pressure, velocity } \\
\text { and saturation effects on } \\
\text { solid and gas solutions, } \\
\text { precipitation reactions and } \\
\text { consumption of solute. } \\
\text { Chemical control on } \\
\text { permeability. }\end{array}$ & $\begin{array}{l}\text { Mechanical } \\
\text { processes control } \\
\text { transport paths - } \\
\text { deformation, } \\
\text { damage and } \\
\text { fracturing. Rock } \\
\text { strength and damage } \\
\text { due to chemical } \\
\text { reactions. }\end{array}$ & Chemical \\
\hline 党 & $\begin{array}{l}\text { Thermal effects on } \\
\text { metabolism of } \\
\text { microorganisms. }\end{array}$ & $\begin{array}{l}\text { "Plugging" - changes in } \\
\text { permeability due to cell } \\
\text { growth within pore } \\
\text { networks. }\end{array}$ & & $\begin{array}{l}\text { Microbially- } \\
\text { induced chemical } \\
\text { changes; } \\
\text { Chemical } \\
\text { stimulation or } \\
\text { inhibition of } \\
\text { microbial growth. }\end{array}$ \\
\hline
\end{tabular}


Table 2. Types of data available for studies on shale, their spatial and temporal resolution, and their process couplings.

\begin{tabular}{|c|c|c|c|c|}
\hline Data type & $\begin{array}{l}\text { Spatial resolution } \\
\text { or size of testable } \\
\text { sample }\end{array}$ & $\begin{array}{l}\text { Temporal } \\
\text { resolution }\end{array}$ & $\begin{array}{l}\text { Couples with }{ }^{\text {a) }} \text { or } \\
\text { strongly affects }\end{array}$ & Comments \\
\hline $\begin{array}{l}\text { Texture (grain size, } \\
\text { shape, orientation } \\
\text { of individual grain, } \\
\text { overall sorting) }\end{array}$ & $\begin{array}{l}\text { Mudrock has }> \\
50 \% \text { of particles } \\
<62.5 \mu \mathrm{m} \text {; fine mud } \\
\text { (clay and very fine } \\
\text { silt) is }<8 \mu \mathrm{m}\end{array}$ & $\begin{array}{l}\text { Time-scale of } \\
\text { depositional } \\
\text { setting (see } \\
\text { Bedding); up to } \\
\text { geological time } \\
\text { for mechanical } \\
\text { diagenesis and } \\
\text { recrystallization }\end{array}$ & $\begin{array}{l}\text { Porosity, } \\
\text { permeability, } \\
\text { capillary pressure } \\
\text { characteristics; } \\
\text { strength, Young's } \\
\text { Modulus }\end{array}$ & $\begin{array}{l}\text { Informs sediment } \\
\text { provenance, water column } \\
\text { energy level, and geologic } \\
\text { controls on rock } \\
\text { properties including } \\
\text { porosity and permeability } \\
\text { (Lazar et al., 2015) }\end{array}$ \\
\hline $\begin{array}{l}\text { Pore network } \\
\text { imaging, pore types } \\
\text { and distribution, } \\
\text { porosity (FIB-SEM, } \\
\text { USAN/SANS, core } \\
\text { plug measurements) } \\
\text { NMR }\end{array}$ & $\begin{array}{l}\mathrm{nm} \text { to } 100 \text { 's of } \mu \mathrm{m} \\
\text { (imaging); } 0.5 \mu \mathrm{m} \\
\text { to } 100 \text { 's of } \mu \mathrm{m} \\
\text { (EDS); } \\
1 \mathrm{~nm} \text { to } 10 \text { 's of } \mu \mathrm{m} \\
\text { (USANS/SANS) } \\
\text { cm's (core plug) }\end{array}$ & $\begin{array}{l}\text { Time-scale of } \\
\text { transport in pore } \\
\text { networks: up to } \\
\text { seconds }\end{array}$ & $\begin{array}{l}\text { Porosity, } \\
\text { permeability, } \\
\text { chemical } \\
\text { composition } \\
\text { /wettability }\end{array}$ & $\begin{array}{l}\text { Direct imaging and } \\
\text { indirect measurements of } \\
\text { porosity and } \\
\text { connectivity-useful for } \\
\text { modeling of pore-scale } \\
\text { transport (including } \\
\text { wettability) and potential } \\
\text { mechanical behavior }\end{array}$ \\
\hline Bedding & $\begin{array}{l}\text { Lamina: fraction of } \\
\text { mm to mm's; } \\
\text { Laminaset: mm to } \\
\text { cm's; } \\
\text { Beds: typically }\end{array}$ & $\begin{array}{l}\text { Laminae: forms } \\
\text { in seconds to one } \\
\text { or more years } \\
\text { Beds: minutes to } \\
\text { "many moments } \\
\text { of geological }\end{array}$ & $\begin{array}{l}\text { "Larger"-scale flow } \\
\text { or mechanical } \\
\text { units; natural } \\
\text { fracture spacing } \\
\text { may correlate with } \\
\text { larger-scale stratal }\end{array}$ & $\begin{array}{l}\text { Relevant for interpreting: } \\
\text { sediment input, } \\
\text { accumulation; energy of } \\
\text { deposition; degree of } \\
\text { bioturbation (Lazar et al., } \\
\text { 2015); curved, wavy }\end{array}$ \\
\hline
\end{tabular}




\begin{tabular}{|c|c|c|c|c|}
\hline & $\begin{array}{l}\text { mm's to } 10 \text { 's of } \\
\mathrm{cm} \text { 's (do not have } \\
\text { minimum or } \\
\text { maximum absolute } \\
\text { thickness); laterally } \\
\text { meters to km's }\end{array}$ & time" $[185]$ & units & $\begin{array}{l}\text { planar (parallel and } \\
\text { nonparallel) affect } \\
\text { heterogeneity and other } \\
\text { transport/mechanical } \\
\text { properties }\end{array}$ \\
\hline $\begin{array}{l}\text { Solid composition } \\
\text { (mineralogy, } \\
\text { chemical } \\
\text { composition, } \\
\text { kerogen type; total } \\
\text { organic carbon) }\end{array}$ & $\begin{array}{l}\text { Can vary from } \\
\text { individual particles } \\
\text { (or cements) to } \\
\text { large-scale } \\
\text { systematic variation } \\
\text { up the bedset or } \\
\text { larger-scale stratal } \\
\text { units (such as } \\
\text { parasequences) }\end{array}$ & $\begin{array}{l}\text { Time-scale } \\
\text { controlling } \\
\text { composition from } \\
\text { seconds } \\
\text { (depositional } \\
\text { setting) to oil and } \\
\text { gas extraction and } \\
\mathrm{CO}_{2} \text { storage (10s } \\
\text { to } 1000 \text { s of years) } \\
\text { to geological time } \\
\text { (diagenesis) }\end{array}$ & $\begin{array}{l}\text { Brine chemistry; } \\
\text { pore-lining phases } \\
\text { and geometry of } \\
\text { pore networks; } \\
\text { (mixed) wettability }\end{array}$ & $\begin{array}{l}\text { Reflects primary } \\
\text { depositional and } \\
\text { diagenetic conditions; } \\
\text { pore-lining phases affect } \\
\text { wettability and chemical } \\
\text { reactivity }\end{array}$ \\
\hline $\begin{array}{l}\text { Fluid chemistry } \\
\text { (brine, fracturing } \\
\text { fluids, hydrocarbon } \\
\text { liquids and gases, } \\
\text { possibly injected } \\
\mathrm{CO}_{2} \text { ) }\end{array}$ & $\begin{array}{l}\text { Single pores to } \\
\text { regional scale }(10 \text { 's } \\
\text { to } 100 \text { 's of } \mathrm{km})\end{array}$ & $\begin{array}{l}\text { Minutes/hours/ } \\
\text { weeks/years for } \\
\text { engineered } \\
\text { (injection); } \\
\text { geologic time } \\
\text { scales for natural } \\
\text { systems }\end{array}$ & $\begin{array}{l}\text { Mineralogy; } \\
\text { permeability, } \\
\text { porosity (coupled } \\
\text { through reactive } \\
\text { transport) and } \\
\text { nano-scale } \\
\text { confinement effects } \\
\text { and phase behavior; } \\
\text { sub-critical fracture }\end{array}$ & $\begin{array}{l}\text { Fluid chemistry can } \\
\text { strongly couple with } \\
\text { many processes } \\
\text { (transport, mechanical } \\
\text { behavior, heat flow, and } \\
\text { microbiology) }\end{array}$ \\
\hline
\end{tabular}




\begin{tabular}{|c|c|c|c|c|}
\hline & & & growth & \\
\hline $\begin{array}{l}\text { Absolute } \\
\text { permeability (and } \\
\text { relative } \\
\text { permeability) }\end{array}$ & $\begin{array}{l}10 \text { 's of microns } \\
\text { (FIB-SEM and } \\
\text { modeling) to } \mathrm{cm} \\
\text { (core plug) }\end{array}$ & $\begin{array}{l}\text { Permeability } \\
\text { evolution of } \\
\text { natural systems: } \\
\text { geological time } \\
\text { scale for } \\
\text { diagenesis; } \\
\text { permeability } \\
\text { evolution can be } \\
\text { over hours, } \\
\text { weeks, days, } \\
\text { years for } \\
\text { engineered } \\
\text { systems }\end{array}$ & $\begin{array}{l}\text { Porosity; pore } \\
\text { pressure } \\
\text { distribution; } \\
\text { drained versus } \\
\text { undrained behavior; } \\
\text { texture, chemistry }\end{array}$ & $\begin{array}{l}\text { Continuum concept; REV } \\
\text { may vary for shales and is } \\
\text { not very well documented } \\
\text { yet and may vary for } \\
\text { different types of pore } \\
\text { structure (e.g., matrix vs } \\
\text { fractures) } \\
\text { Relative permeability is } \\
\text { not routinely measured in } \\
\text { mudrocks }\end{array}$ \\
\hline $\begin{array}{l}\text { Capillary pressure } \\
\text { curves and pore- } \\
\text { throat size } \\
\text { distributions }\end{array}$ & $\begin{array}{l}\text { cm (core plug); } \\
\text { possibility down to } \\
100 \text { 's of microns if } \\
\text { using FIB-SEM } \\
\text { data and a modeling } \\
\text { method (e.g., LB) }\end{array}$ & $\begin{array}{l}\text { Probably up to } \\
\text { seconds of } \\
\text { transport (in FIB- } \\
\text { SEM models) }\end{array}$ & $\begin{array}{l}\text { Porosity, } \\
\text { permeability, } \\
\text { textural analysis; } \\
\text { activity of water or } \\
\text { fluids in nano-scale } \\
\text { confined pore } \\
\text { networks }\end{array}$ & $\begin{array}{l}\text { Capillary imbibition } \\
\text { strongly coupled with } \\
\text { texture }\end{array}$ \\
\hline $\begin{array}{l}\text { Effective diffusion } \\
\text { coefficient }\end{array}$ & $\begin{array}{l}\text { cm (core plug); } \\
\text { possibility down to } \\
100 \text { 's of microns if } \\
\text { using FIB-SEM } \\
\text { data }\end{array}$ & $\begin{array}{l}\text { Geologic time } \\
\text { scales for natural } \\
\text { transport } \\
\text { processes; large } \\
\text { surface area of } \\
\text { induced fractures }\end{array}$ & $\begin{array}{l}\text { Texture } \\
\text { (topology/tortuosity } \\
\text { of pore networks); } \\
\text { porosity }\end{array}$ & $\begin{array}{l}\text { Diffusion processes may } \\
\text { range from Ordinary } \\
\text { Fickian to Knudsen } \\
\text { diffusion }\end{array}$ \\
\hline
\end{tabular}




\begin{tabular}{|c|c|c|c|c|}
\hline & & $\begin{array}{l}\text { may reduce time } \\
\text { scales to that of } \\
\text { reservoir } \\
\text { production }\end{array}$ & & \\
\hline $\begin{array}{l}\text { Sorption / } \\
\text { adsorption } \\
\text { isotherms }\end{array}$ & $\begin{array}{l}\mathrm{mm} \text { to } \mathrm{cm} \text { (core } \\
\text { plug or crushed } \\
\text { samples) }\end{array}$ & $\begin{array}{l}\text { Seconds; may } \\
\text { depend on } \\
\text { reservoir pressure } \\
\text { and thus time } \\
\text { scales of field } \\
\text { operations (years) }\end{array}$ & $\begin{array}{l}\text { Texture, } \\
\text { composition, fluid } \\
\text { compositions, } \\
\text { permeability }\end{array}$ & $\begin{array}{l}\text { Consider } \\
\text { sorption/desorption for } \\
\text { fine-grained minerals and } \\
\text { organic material }\end{array}$ \\
\hline $\begin{array}{l}\text { Geomechanics and } \\
\text { constitutive models: } \\
\text { Young Modulus } \\
\text { and Poisson ratio } \\
\text { (isotropic); } \\
\text { Transversely } \\
\text { isotopic (five } \\
\text { parameters); critical } \\
\text { state mechanics; } \\
\text { general plasticity; } \\
\text { failure models and } \\
\text { parameters (e.g., } \\
\text { Mohr-Coulomb) }\end{array}$ & $\begin{array}{l}\text { From micron } \\
\text { (nanoindentation) } \\
\text { to cm (core plug); } \\
\text { core plugs may } \\
\text { need to be taken at } \\
\text { different angles for } \\
\text { estimates of } \\
\text { transversely or fully } \\
\text { anisotropic } \\
\text { parameters }\end{array}$ & $\begin{array}{l}\text { Seconds, hours, } \\
\text { weeks } \\
\text { (engineered) to } \\
\text { geological } \\
\text { timescales } \\
\text { (natural) }\end{array}$ & $\begin{array}{l}\text { Porosity, pore } \\
\text { network properties, } \\
\text { texture, } \\
\text { composition, } \\
\text { diagenetic textures }\end{array}$ & $\begin{array}{l}\text { Some parameters may be } \\
\text { dynamically estimated } \\
\text { from seismic wave } \\
\text { velocities; sophistication } \\
\text { of geomechanical } \\
\text { properties estimated can } \\
\text { vary greatly }\end{array}$ \\
\hline $\begin{array}{l}\text { Unconfined } \\
\text { compressive } \\
\text { strength }\end{array}$ & $\begin{array}{l}\text { micron to } \mathrm{mm} \text { to } \\
\mathrm{cm} \text { (micron } \\
\text { indenter on FIB-ed } \\
\text { columns; calibrated }\end{array}$ & $\begin{array}{l}\text { Seconds, hours, } \\
\text { weeks } \\
\text { (engineered) to } \\
\text { geological }\end{array}$ & $\begin{array}{l}\text { Porosity, pore } \\
\text { network properties, } \\
\text { texture, } \\
\text { composition, fluid }\end{array}$ & $\begin{array}{l}\text { In situ stress state, } \\
\text { including magnitudes, } \\
\text { directions, and pore } \\
\text { pressure distribution }\end{array}$ \\
\hline
\end{tabular}




\begin{tabular}{|c|c|c|c|c|}
\hline & $\begin{array}{l}\text { scratch test; core } \\
\text { plugs) }\end{array}$ & $\begin{array}{l}\text { timescales } \\
\text { (natural) }\end{array}$ & $\begin{array}{l}\text { composition } \\
\text { contacting fracture } \\
\text { process zone, } \\
\text { chemistry-related }\end{array}$ & $\begin{array}{l}\text { should be taken into } \\
\text { account in predicting } \\
\text { subsurface behavior }\end{array}$ \\
\hline Fracture toughness & $\begin{array}{l}\text { From micron } \\
\text { (nanoindentation) } \\
\text { to } \mathrm{cm} \text { (double- } \\
\text { torsion) }\end{array}$ & $\begin{array}{l}\text { Seconds, hours, } \\
\text { weeks } \\
\text { (engineered) to } \\
\text { geological } \\
\text { timescales } \\
\text { (natural) }\end{array}$ & $\begin{array}{l}\text { Porosity, pore } \\
\text { network properties, } \\
\text { texture, } \\
\text { composition, fluid } \\
\text { composition } \\
\text { contacting fracture } \\
\text { process zone }\end{array}$ & $\begin{array}{l}\text { In situ stress state and } \\
\text { fluid composition should } \\
\text { be taken into account }\end{array}$ \\
\hline $\begin{array}{l}\text { Tracer logs or } \\
\text { spinner surveys; } \\
\text { distributed fiber } \\
\text { optic sensing }\end{array}$ & $\begin{array}{l}\text { 10's of cm, up to } \\
\text { length of } \\
\text { completion of } \\
\text { wellbore }\end{array}$ & $\begin{array}{l}\text { Hours, weeks, } \\
\text { years (for } \\
\text { permanently } \\
\text { installed fiber } \\
\text { optic arrays) }\end{array}$ & $\begin{array}{l}\text { Porosity, } \\
\text { permeability, } \\
\text { fracture network } \\
\text { characteristics }\end{array}$ & $\begin{array}{l}\text { Tracer logging and } \\
\text { spinner surveys may } \\
\text { reflect aspects of } \\
\text { completions and the } \\
\text { reservoir itself }\end{array}$ \\
\hline $\begin{array}{l}\text { Production decline } \\
\text { analysis; pressure or } \\
\text { rate transient } \\
\text { analysis: yields } \\
\text { estimates of a } \\
\text { variety of reservoir } \\
\text { parameters }\end{array}$ & $\begin{array}{l}\text { Length scale of } \\
\text { fracture spacing; } \\
\text { provides } \\
\text { information on the } \\
\text { entire length of } \\
\text { completion of } \\
\text { wellbore }\end{array}$ & $\begin{array}{l}\text { Months to } \\
\text { decades; the } \\
\text { progression of } \\
\text { flow regimes in } \\
\text { shale reservoirs } \\
\text { may take decades } \\
\text { to develop }\end{array}$ & $\begin{array}{l}\text { Integrates } \\
\text { permeability } \\
\text { (potentially } \\
\text { temporally } \\
\text { varying), porosity, } \\
\text { multi-phase flow; } \\
\text { may include double } \\
\text { porosity }\end{array}$ & $\begin{array}{l}\text { Attempts to invert for } \\
\text { reservoir parameters and } \\
\text { reverses or oil/gas in } \\
\text { place, and forecasts } \\
\text { production }\end{array}$ \\
\hline $\begin{array}{l}\text { Wireline } \\
\text { measurements }\end{array}$ & $\begin{array}{l}\text { Resolution } 1-2 \text { feet } \\
(30-60 \mathrm{~cm})\end{array}$ & $\begin{array}{l}\text { Wireline } \\
\text { measurements on }\end{array}$ & $\begin{array}{l}\text { Porosity, } \\
\text { permeability, and }\end{array}$ & $\begin{array}{l}\text { Important tools for } \\
\text { measurements of reservoir }\end{array}$ \\
\hline
\end{tabular}




\begin{tabular}{|l|l|l|l|l|}
\hline $\begin{array}{l}\text { (neutron porosity, } \\
\text { gamma ray, well } \\
\text { resistivity, NMR, in } \\
\text { situ fluid } \\
\text { saturations, etc) }\end{array}$ & order or hours & fluid composition & $\begin{array}{l}\text { properties over length of } \\
\text { completed zones }\end{array}$ \\
\hline Microseismic & 10 's of meters & $\begin{array}{l}\text { Probably hours } \\
\text { for measurements }\end{array}$ & $\begin{array}{l}\text { Poroisty, } \\
\text { permeability, } \\
\text { geomechanical } \\
\text { properties }\end{array}$ & $\begin{array}{l}\text { Important for mapping } \\
\text { fracture complexity at the } \\
\text { wellbore scale }\end{array}$ \\
\hline
\end{tabular}

Notes:

a) Identifies where methodologies for integrating multi-disciplinary data are well established 
Figure captions

Figure 1. Structures, processes, and the relevant length scales for shale formations.

Figure 2. Intense layering with contrasting properties in shales. Outcrops photos (top), and scanning electron microscope (SEM) images (bottom).

Figure 3. Elemental composition of shale measured by $x$-ray fluorescence (XRF) with centimeter-resolution. The presence and distribution of calcite-rich layers intermixed with mudstone units is observed over an $85 \mathrm{ft}$. $(25 \mathrm{~m})$ section.

Figure 4. Healed bedding plane fracture in Eau Claire Formation, a major seal for the Mt. Simon Sandstone in the mid-continent of the U.S.

Figure 5. (a) Borehole breakouts result along preferential direction under a uniform stress field, because the presence of planes of weakness in the rock; (b) Hydraulic fracture grows by overcoming one layer at a time, despite the imposed uniform stress field; (c and d) Thin mineralized interfaces and weak bedding control the propagation of fractures during fracture toughness experiments; (e) Fish-bone structures of fracture propagation and fluid leak off are common on laboratory hydraulic fracturing experiments on laminated shales.

Figure 6. Acoustic wavefronts propagated through garolite (fiberglass-epoxy laminate) sample with a set of parallel fractures. Stress was applied perpendicular to the fractures (solid black lines) or parallel to the layering (dashed gray lines).

Figure 7. (a) Dual beam focused ion beam (FIB)/SEM 3-D volume, (b) 3-D rendering of kerogen and (c) 3-D rendering of the pores in this volume of the Pt. Pleasant formation, Wood Co. West Virginia, 9503 ft depth. Re-printed from Arthur and Cole., 2014.

Figure 8. Left: Three-dimensional pore network model consisting of nano-capillaries shown in two-dimensions for nanopore Pn. The model has been developed and used to investigate kerogen 
REV by Rui et al., 2016. Right: estimated permeability of the kerogen nanopore network as a function of the network volume for changing coordination number, Z. Methane transport is considered (including convection, diffusion and adsorption mechanisms) at average pore pressure of $2,500 \mathrm{psi}$, and temperature $80^{\circ} \mathrm{C}(353 \mathrm{~K})$.

Figure 9. Left: Schematic illustrating the uniform distribution of micro-cracks and their orientation angle $\theta$ in a cross section of organic-rich shale in vertical direction. The organic-rich shale is shown as gray background. Directions of vertical and horizontal minimum stresses are also shown. Right: Permeability tensor $\mathrm{k}_{\mathrm{m}}$ elements for various microcrack orientation angle $(\theta)$ with $\mathrm{k}_{\mathrm{z}^{\prime} \mathrm{z}}=0$.

Figure 10. Phase diagrams of methane (top, left) and n-butane (top, right) in 4 and $8 \mathrm{~nm}$ size pores obtained from simulations and compared to bulk behavior. Phase diagram of binary methane-n-butane mixture (bottom). The bulk behavior is extracted from Peng-Robinson equation of state. Adopted from Akkutlu and Rahmani 2015.

Figure 11. Left: Organic pore wall model with surface heterogeneities. Carbon is shown in brown, hydrogen in yellow and nitrogen in blue. Right: Predicted storage of methane in the pore in adsorbed form (solid line) and excess (dashed line) methane. Predictions are based on grand canonical ensemble molecular simulations where the Lennard-Jones parameters $(\varepsilon, \sigma)$ of methane-wall interactions have been estimated using quantum mechanical (DFT) calculations and ground-state energy optimization. Adopted from Cristancho et al., 2016.

Figure 12. Osmotic pressure increase by the hydraulic fracture as a function of shut-in time at various locations $(1,5,10,50$, and $100 \mathrm{~cm})$ in the shale matrix near the fracture. The simulation involves flow of water in a rock (semipermeable membrane) driven by the pressure and chemical potential gradient. Membrane efficiency is 0.1 (top) and 1.0 (bottom). Osmotic pressure increase is defined as the difference between the initial pore pressure and pore pressure after fluid invasion. A constant pressure is applied on the left boundary. The objective of the simulation is to understand the effect of hydraulic fracturing water with low salinity (equivalent $\mathrm{NaCl}$ concentration of $10,000 \mathrm{ppm}$ ) on the adjacent shale matrix containing formation water with higher salinity $(50,000 \mathrm{ppm})$. The initial pressure is $3,000 \mathrm{psi}$ and temperature is $50^{\circ} \mathrm{C}$. The rock 
has permeability of $200 \mathrm{nD}$ and porosity of $10 \%$. The further most left cell has a constant pressure of $3,000 \mathrm{psi}$, which is representing shut-in pressure in the fracture, temperature of $50^{\circ} \mathrm{C}$.

Figure 13. The typical measurement resolution (see Table 2), and modeling methods used for single and coupled processes in shale. 


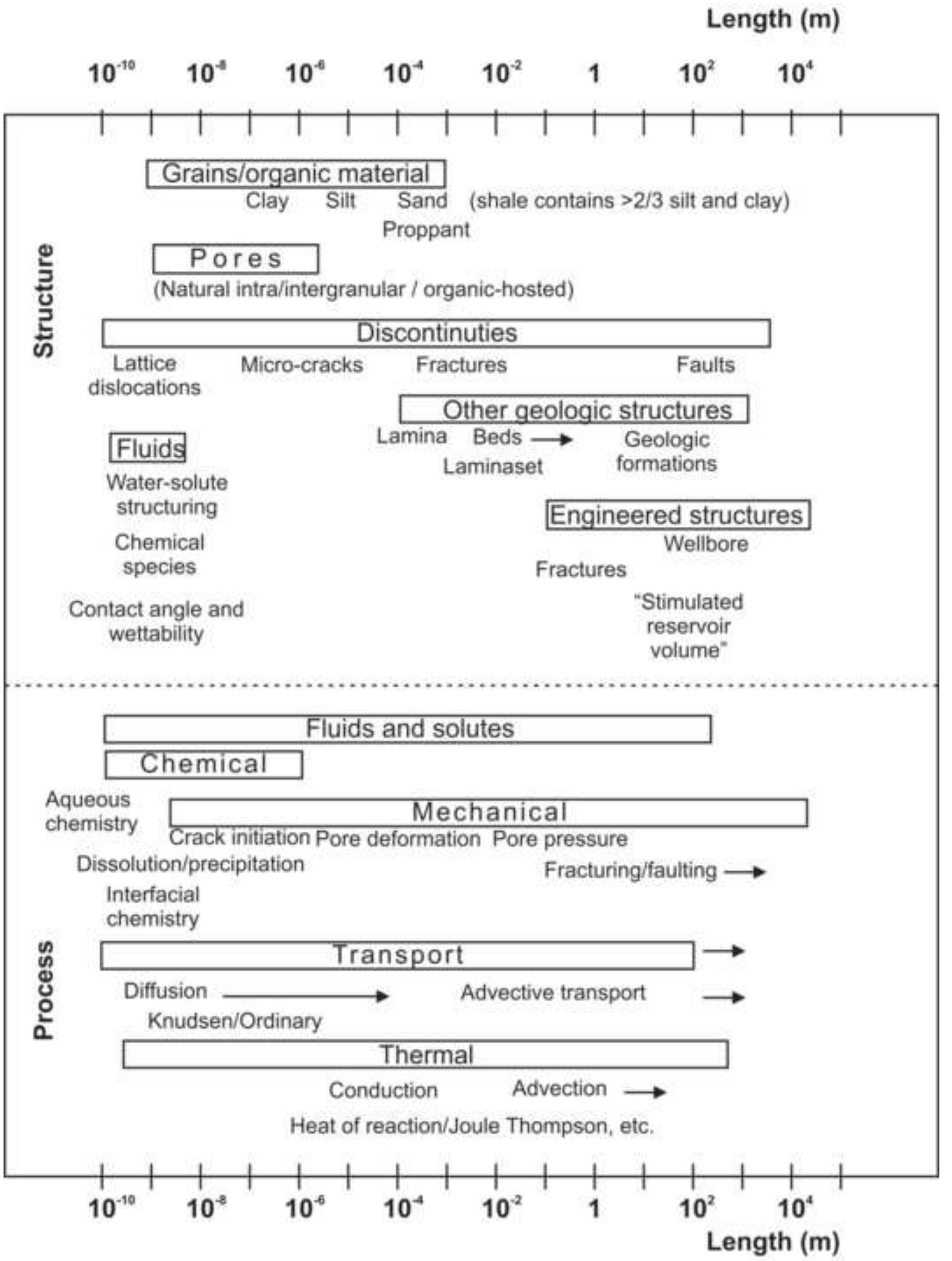



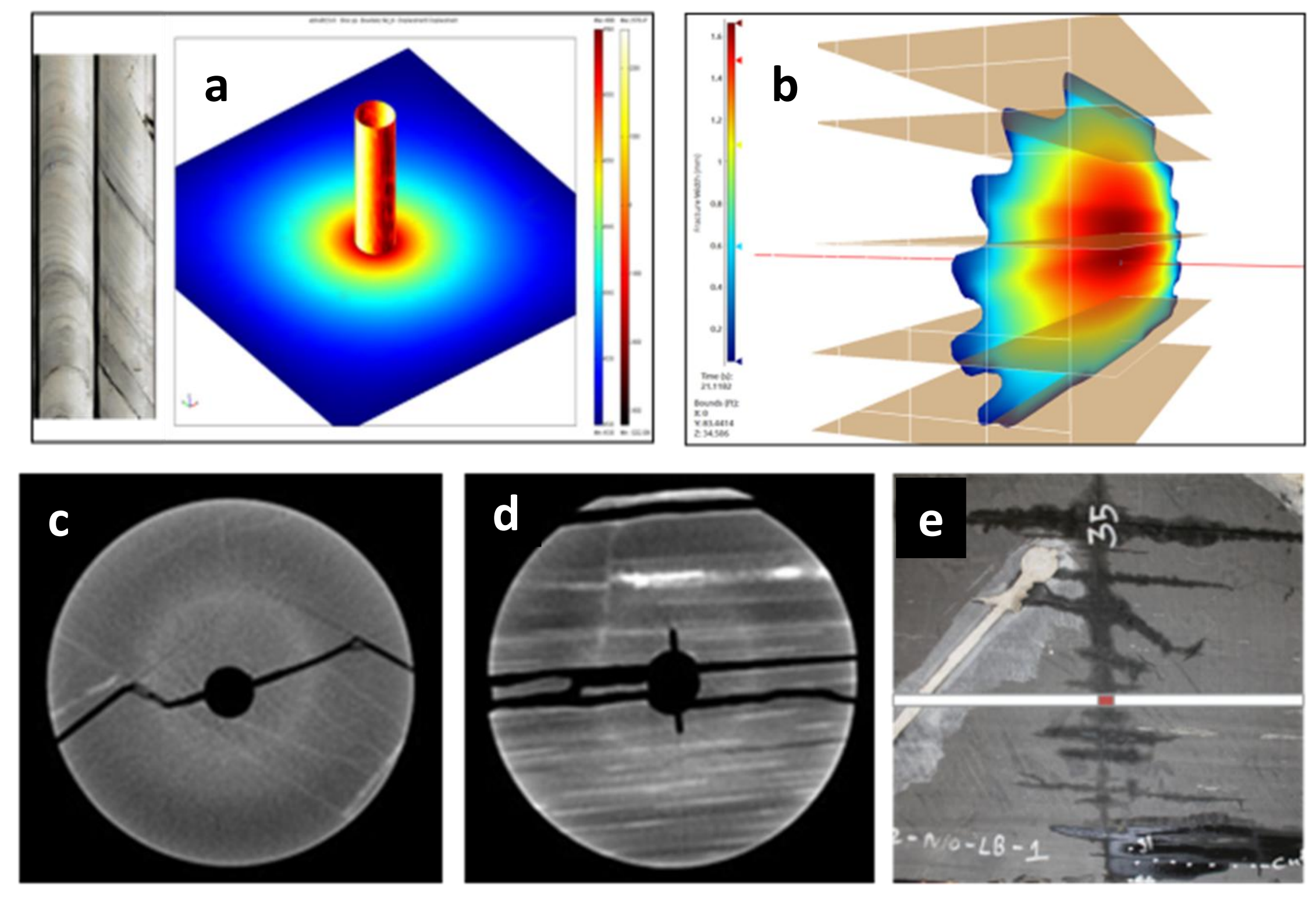


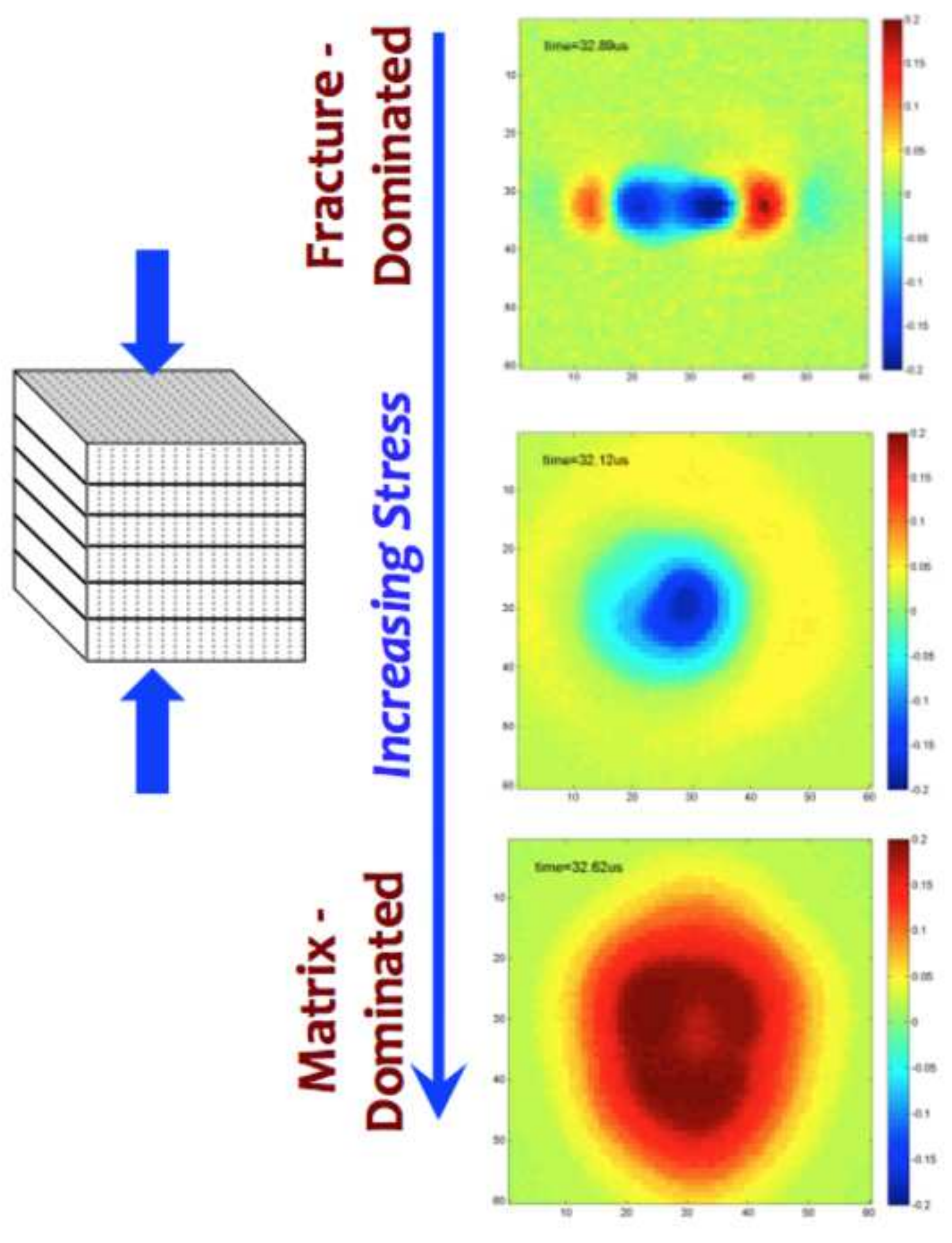

Figure 6

.

.
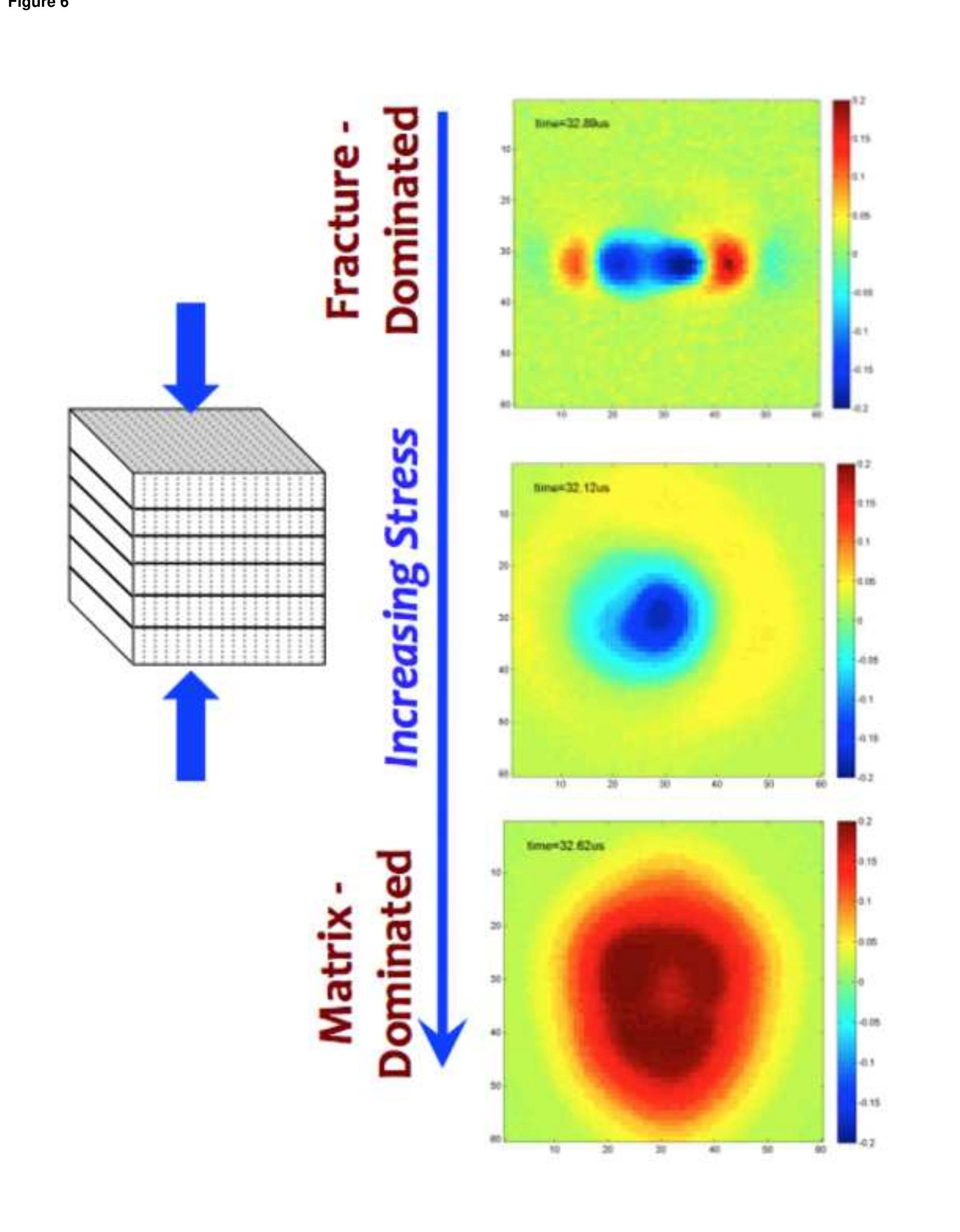


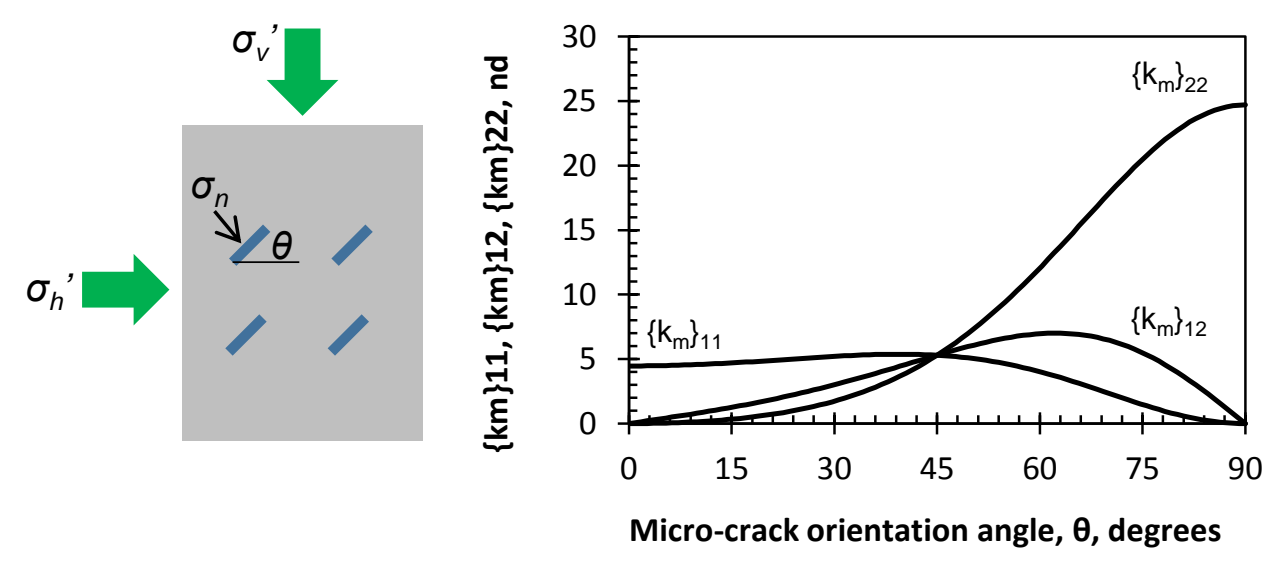



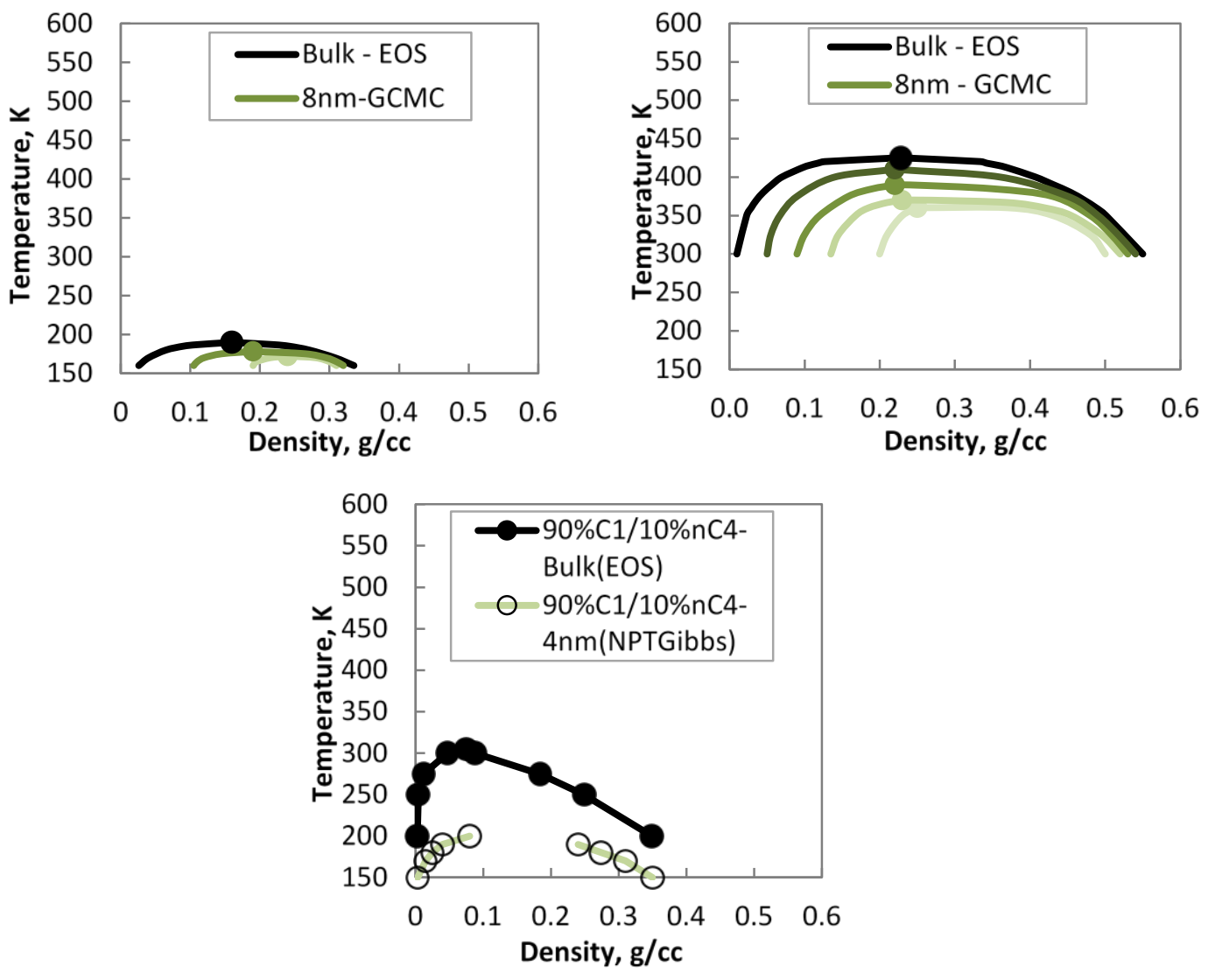

Density, g/cc 

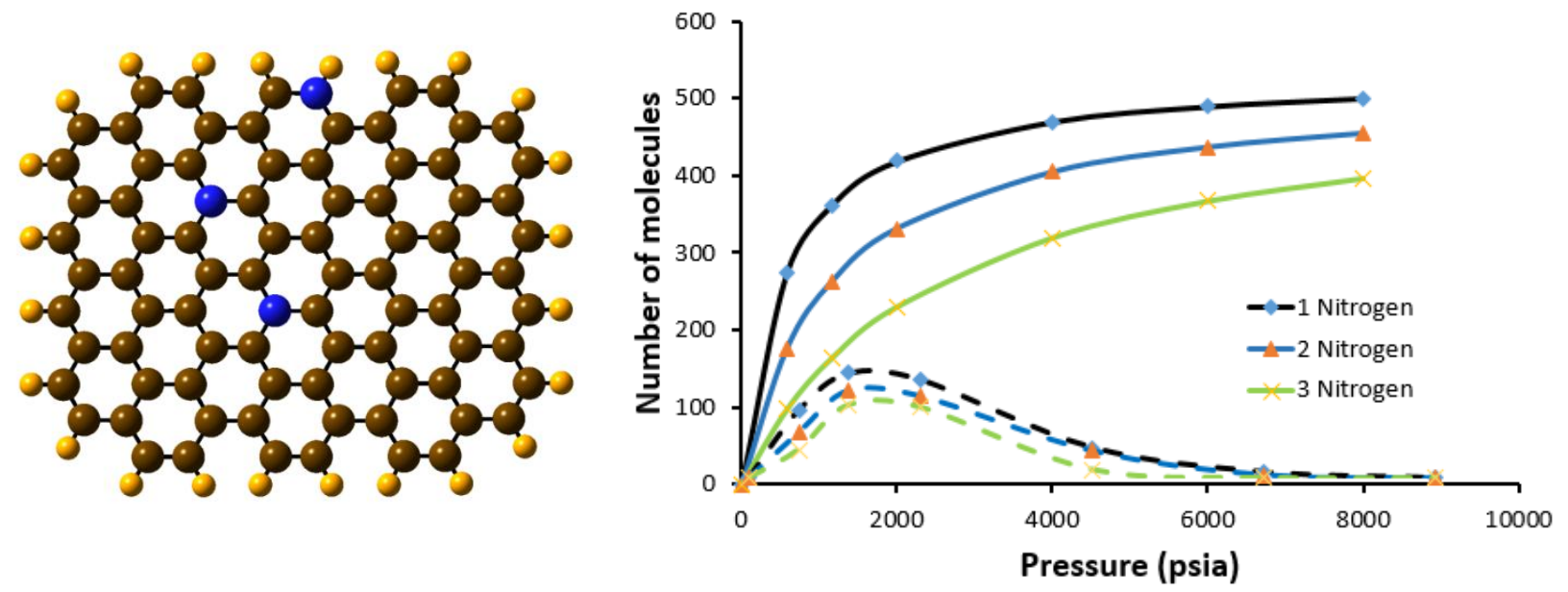


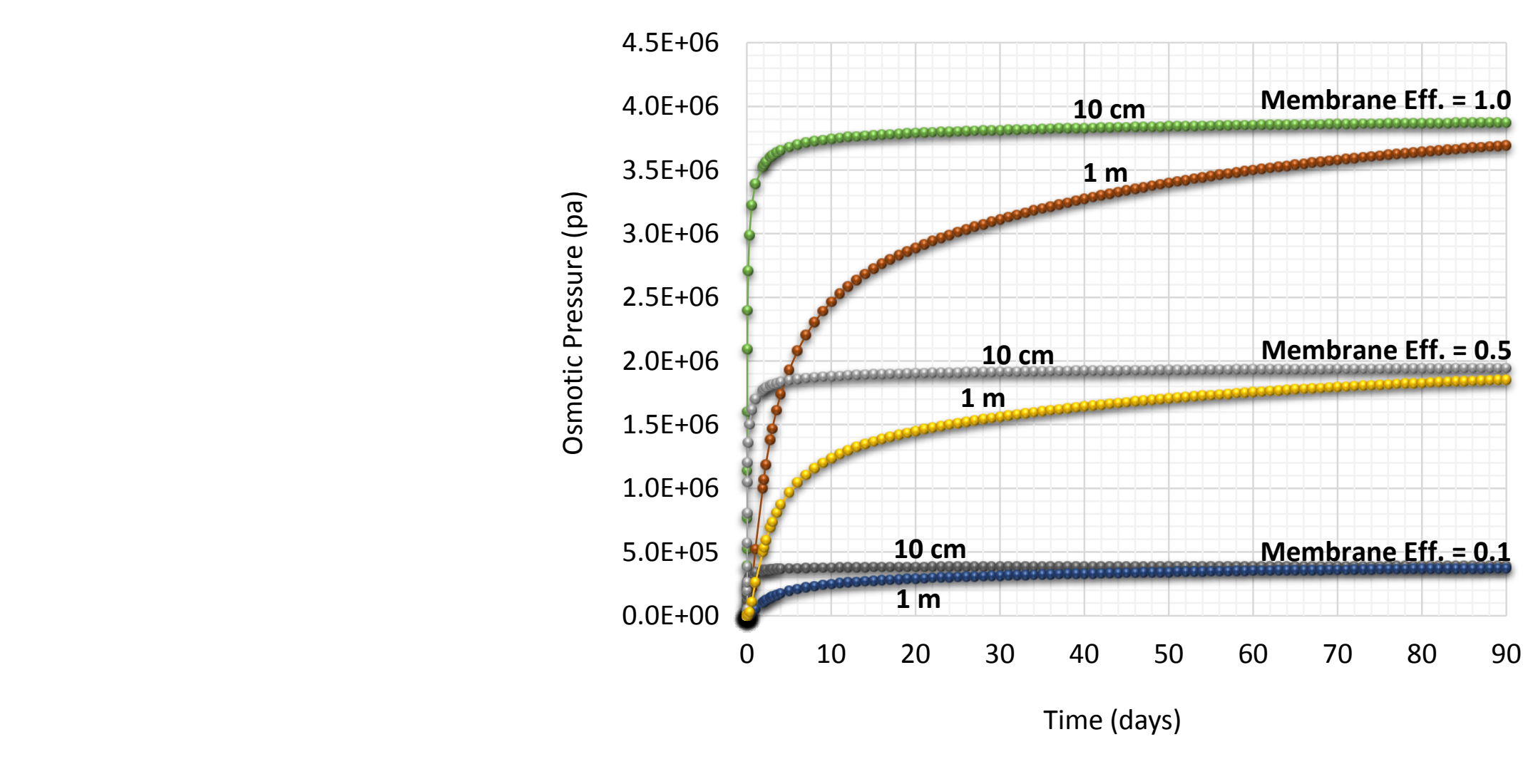

Time (days) 
Length $(\mathrm{m})$

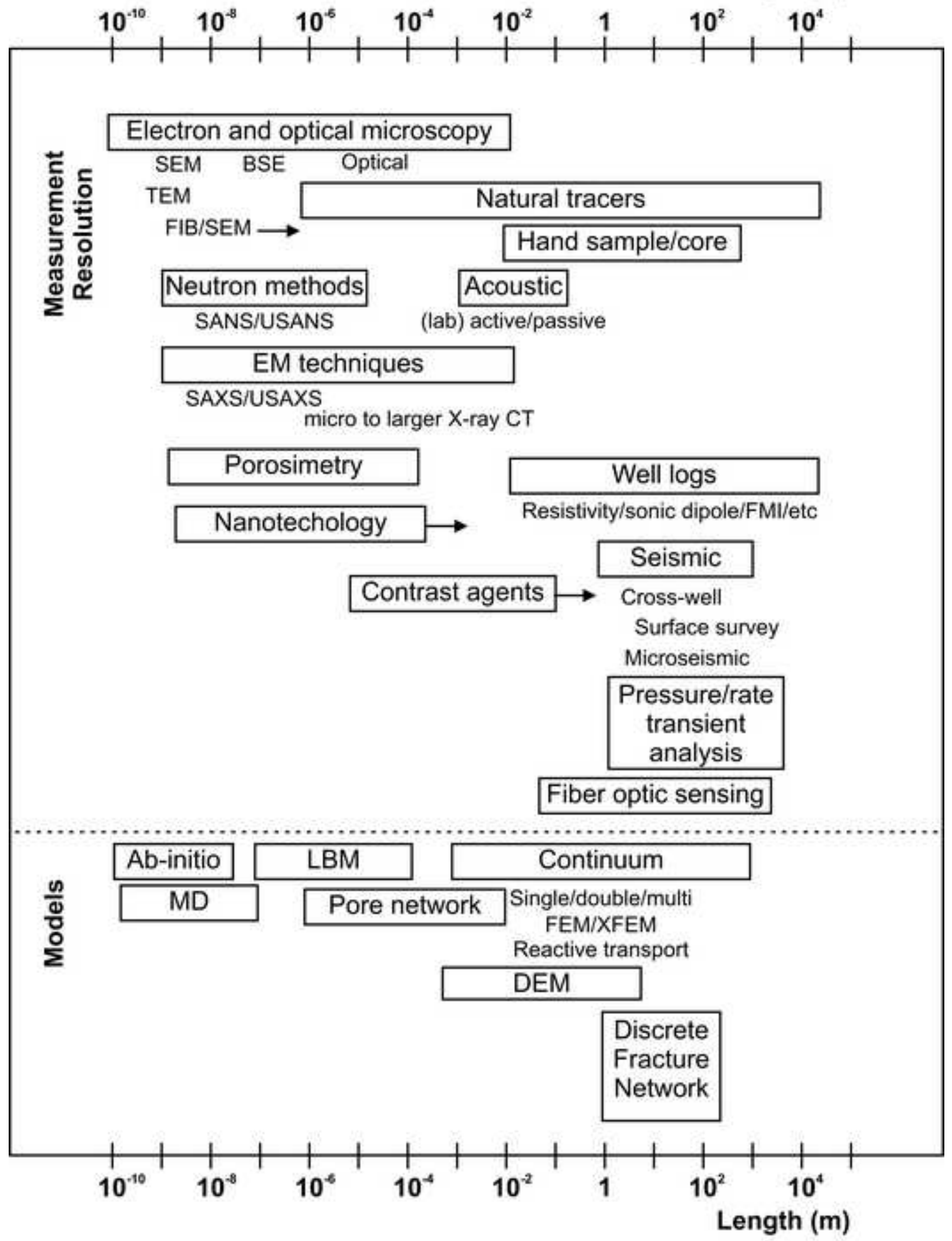

